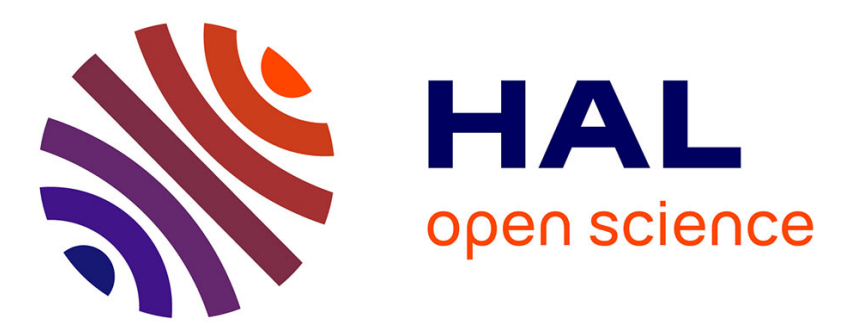

\title{
The influence of igneous processes on the chromium isotopic compositions of Ocean Island basalts
}

P. Bonnand, R. Doucelance, M. Boyet, P. Bachèlery, C. Bosq, D. Auclair, P. Schiano

\section{- To cite this version:}

P. Bonnand, R. Doucelance, M. Boyet, P. Bachèlery, C. Bosq, et al.. The influence of igneous processes on the chromium isotopic compositions of Ocean Island basalts. Earth and Planetary Science Letters, 2020, 532, pp.116028. 10.1016/j.epsl.2019.116028 . hal-02437951

\section{HAL Id: hal-02437951 \\ https://hal.uca.fr/hal-02437951}

Submitted on 14 Jan 2020

HAL is a multi-disciplinary open access archive for the deposit and dissemination of scientific research documents, whether they are published or not. The documents may come from teaching and research institutions in France or abroad, or from public or private research centers.
L'archive ouverte pluridisciplinaire HAL, est destinée au dépôt et à la diffusion de documents scientifiques de niveau recherche, publiés ou non, émanant des établissements d'enseignement et de recherche français ou étrangers, des laboratoires publics ou privés. 
6

7

8

9

5

\title{
The influence of igneous processes on the chromium isotopic compositions of Ocean Island basalts
}

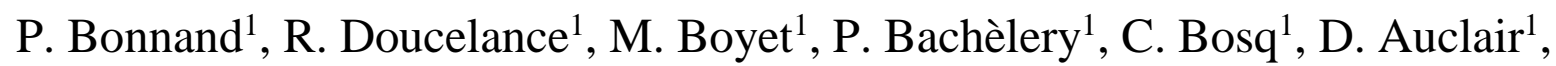 \\ P. Schiano ${ }^{1}$
}

\section{(1)}

${ }^{1}$ Université Clermont Auvergne, CNRS, Laboratoire Magmas et Volcans, F-63000 ClermontFerrand, France.

$21 *$ Corresponding author

22 Email address: pierre.bonnand@uca.fr

23 Tel. No: +33 (0)473346783

4 Fax No: +33(0)473346744 
Abstract:

We present the first stable chromium isotopic data for a suite of ocean island basalts (OIB) in order to investigate the $\mathrm{Cr}$ isotope fractionation during major igneous processes such as partial melting and fractional crystallisation. Twenty-one basaltic samples from Fangataufa Island (Tuamotu Archipelago, Pacific Ocean) have been analysed for major- and trace-element concentrations, and $\mathrm{Sr}, \mathrm{Nd}$ and $\mathrm{Cr}$ isotopic compositions. They define two distinct series: medium to high-K calc-alcaline and low to medium-K calc-alcaline. The variations in incompatible elements such as $\mathrm{La}$ and $\mathrm{Yb}$ mostly result from varying degrees of partial melting of a mixed mantle source composed of two lithologies: garnet bearing peridotite and a "fertile" component. The recycled component is also identified with the $\mathrm{Sr}$ and $\mathrm{Nd}$ isotopic composition of Fangataufa basalts. In contrast, the variations in compatible element contents such as $\mathrm{Cr}$ and $\mathrm{Ni}$ are governed by fractional crystallisation of a mixture of olivine, clinopyroxene and spinel. The samples analysed in this study are also characterised by small $\mathrm{Cr}$ isotope variations from 0.24 to $-0.17 \%$. The $\mathrm{Cr}$-poor samples have on average lighter $\mathrm{Cr}$ isotopic compositions compared to Cr-rich ones. The observed variations in the low-K series can be modelled by a Rayleigh fractionation model with a fractionation factor $\left(\Delta^{53} \mathrm{Cr}_{\text {crystals-melt }}\right)$ of $-0.010 \pm 0.005 \%$. The fractionation is more limited than that observed in lunar basalts and two hypotheses may explain this observation: a change in crystallising phases (cpx + spinel on Earth and spinel on the Moon) and/or the difference in temperature and oxygen fugacity between the crystallisation of lunar and terrestrial basalts. The more primitive basalts from Fangataufa have an average $\mathrm{Cr}$ isotopic composition of $-0.18 \pm 0.01 \%$, lighter than the $\mathrm{Cr}$ isotopic composition of pristine mantle xenoliths. Chromium isotopes are therefore slightly fractionated during partial melting with the melts depleted in heavy $\mathrm{Cr}$ isotopes. The difference between silicate melts and mantle xenoliths indicates that partial melting could produce small but resolvable shift in mantle xenoliths $\mathrm{Cr}$ isotopic composition of up to $0.05 \%$. The covariation between $\delta^{53} \mathrm{Cr}$ and $\varepsilon^{143} \mathrm{Nd}$ values in Fangataufa basalts can be explained by two processes: (i) lower degree of partial melting produce lighter $\mathrm{Cr}$ isotopic composition in basaltic liquids relative to their sources and (ii) melts produced by low degree of partial melting have also experienced more fractional crystallisation.

1 Keywords: Cr isotopes, Ocean Island Basalts, partial melting, magmatic differentiation, Fangataufa 62 Archipelago. 


\section{Introduction}

The knowledge of the isotopic composition of the Earth and its main reservoirs is fundamental to understand the evolution of our planet through time. For this purpose, radiogenic isotopes have been extensively studied over the last decades. More recently, non-conventional stable isotopes have been also used to constrain the chemical evolution of planetary reservoirs (e.g. Dauphas et al. 2012, Sossi et al. 2018). High-temperature, mass-dependent stable isotope variations have indeed been discovered, opening a new way to interrogate the geological record and to constrain the chemical reactions during differentiation (e.g. Teng et al. 2008). However, contrary to radiogenic isotopes, mass dependent stable isotopes can be fractionated by igneous processes (Xia et al. 2017, Tang et al. 2017). It is therefore essential to constrain the behaviour of stable isotopes during partial melting and fractional crystallisation of basaltic system in order to use them as efficient tracers of the Cr isotopic composition of planetary reservoirs.

Chromium has a half-nebular condensation temperature of $1296 \mathrm{~K}$ which makes it a moderately volatile element (Lodders 2003) although many studies have classified chromium as "medium refractory" (Allègre et al. 2001). Chromium is a moderately siderophile element with metal-silicate partition coefficient ranging from 2.5 to 3.5 when determined at core formation conditions (Wood et al. 2008, Siebert et al. 2011, Clési et al. 2016). The siderophile behaviour of chromium depends on temperature and oxygen fugacity (e.g. Siebert et al. 2011). Finally, chromium behaves compatibly during partial melting of the upper mantle and fractional crystallisation of basaltic systems. $\mathrm{The} \mathrm{Cr}$ compatibility during partial melting of the mantle strongly depends on temperature and $\mathrm{Cr}$ becomes less compatible with increasing temperature (Liang and Elthon 1990). The main Cr-bearing phases in the upper mantle are spinel (or garnet at high pressure) and pyroxenes (Murck and Campbell 1986; Li et al. 1995). In natural high temperature systems, chromium can be present in multiple oxidation $\mathrm{states} \mathrm{Cr}^{0}$ in metal melt, $\mathrm{Cr}^{2+}$ and $\mathrm{Cr}^{3+}$ in silicate melts and minerals, and $\mathrm{Cr}^{3+}$ in oxide minerals (Berry et al. 2004, Berry et al. 2006, Li et al. 1995). At $1400^{\circ} \mathrm{C}$, in MORB glass composition, $50 \%$ of the $\mathrm{Cr}$ is trivalent at the QFM buffer (Berry et al. 2006). The redox behaviour of chromium makes it a key element to study variations in oxygen fugacity and redox reactions in natural systems. The estimate for the bulk 
silicate Earth (BSE) and the core Cr concentrations vary from 2500 to $2800 \mu \mathrm{g} \mathrm{g}^{-1}$ (McDonough and Sun 1995, Palme and O'Neill 2014) and from 5500 to $9000 \mu \mathrm{g} \mathrm{g}^{-1}$ (Allègre et al. 1995, Javoy et al. 2010, McDonough 2013), respectively. Typical variations of $\mathrm{Cr}$ concentrations in mantle xenoliths have been linked to partial melting and for terrestrial basalts to fractional crystallisation processes (e.g. Li et al. 1995). These variations and their causes need to be precisely addressed before determining the initial $\mathrm{Cr}$ concentration in the primary liquids of terrestrial basalts and in the primitive mantle material. Chromium isotopes have been studied recently in a number of terrestrial and extra-terrestrial samples (e.g. Schoenberg et al. 2008, Farkas et al. 2016, Wang et al. 2016, Bonnand et al. 2016a, Bonnand et al. 2016b). The variations in Cr isotopes are reported using the notation:

$$
\delta^{53} \mathrm{Cr}=\left(\frac{{ }^{53} \mathrm{Cr} /{ }^{52} \mathrm{Cr}}{\text { sample }}-1\right) \times 1000
$$

Most recent analyses on mantle xenoliths and mineral separates have shown that $\mathrm{Cr}$ isotopes are fractionated during partial melting (Xia et al. 2017). The residues become heavier while partial melting proceeds and the melts are therefore believed to be lighter than the residues although no melts have yet been analysed at high precision. Furthermore, mineral separates data reveal that at equilibrium, the $\mathrm{Cr}$ isotopic composition become heavier in the order olivine $\leq \mathrm{cpx}=\mathrm{opx}<\operatorname{spinel}$ (Shen et al. 2018). It has also been demonstrated that $\mathrm{Cr}$ are fractionated during magmatic differentiation on the Moon (Bonnand et al. 2016b). Comparing Cr isotope signatures in samples from different planetary bodies is challenging because planetary processes may have affected the composition of the major reservoirs. The difference in isotopic composition between the Moon and the Earth has been attributed to the volatility of Cr during cooling and accretion on the Moon in the aftermath of the giant impact (Sossi et al. 2018). For HEDs meteorites (Howardite-Eucrite-Diogenite), both volatility and magmatic processes could play a role in their Cr isotopic compositions (Zhu et al. 2019, Bonnand et al. 2016b). Iron meteorites are characterised by heavy $\mathrm{Cr}$ isotopic compositions compared to terrestrial samples, which have been explained by fractional crystallisation in the liquid iron (Bonnand and Halliday 2018). The similarity between the $\mathrm{Cr}$ isotopic compositions of the bulk silicate Earth estimates and chondritic material suggests that there is no fractionation during core formation on Earth (Bonnand et al. 2016a, Schoenberg et al. 2016). 

partial melting and fractional crystallisation, direct measurements are still lacking. Two studies have presented $\mathrm{Cr}$ isotopic composition in terrestrial basaltic rocks (Schoenberg et al. 2008; Xia et al. 2017).

Resolvable variations were observed but the limited number of samples did not allow to determine the behaviour of $\mathrm{Cr}$ isotopes during partial melting and/or fractional crystallisation. Here, we investigate the $\mathrm{Cr}$ isotopic composition of basalts from one oceanic island: Fangataufa, Pacific Ocean. In order to determine the initial $\mathrm{Cr}$ isotopic composition of the parental melt we investigate the isotopic fractionation resulting from fractional crystallisation and assess whether these fractionations are comparable to those observed in other planetary bodies. Once the primary melt has been defined, we also investigate the fractionation happening during partial melting. of both sub-aerial and submarine volcanic rocks topped by carbonate sediments (Schiano et al. 1990). Our samples have been selected to span the entire sequence recorded there (sample depth from $-929 \mathrm{~m}$ to $-458 \mathrm{~m}$, see supplementary information file). In detail, the samples have been classified into three main lithologies: submarine lava flows, dykes and sills, and monolithological hyaloclastites. Previous studies have shown limited variations in the major element concentrations of volcanic rocks: the samples are mainly basalts or trachy-basalts and a continuous evolution between alkaline series and a transitional series was observed at "Terme Sud" drill core (Fig. S1, Schiano et al. 1990, Dupuy et al. 1993, Schiano et al. 1993). The Fangataufa basalts are characterised by typical OIB REE patterns with LREE enrichment relative to $\mathrm{HREE}\left(\mathrm{Ce} / \mathrm{Yb}_{\mathrm{N}}=8.8\right.$, Dupuy et al. 1993). They also have incompatible trace element ratios (Th/La, Ba/La, Hf/Sm) in the same range as other OIBs (Dupuy et al. 1993). Partial melting is the dominant igneous process that controls the variations in incompatible trace element contents (Dupuy et al. 1993). By fractional crystallization, Fangataufa submarine lavas evolve also from 
picrites to basalts whereas subaerial lavas, which correspond to the end of the volcanic activity, evolve from picrites to hawaiites. Some of the samples have also experienced secondary processes that altered their original signatures (Schiano et al. 1990). The main process is seawater-rock interaction (some of the samples have been emplaced under-water), although alteration during late hydrothermal fluid circulation was also reported. Lastly, volcanic products from Fangataufa have been studied for their ${ }^{87} \mathrm{Sr} /{ }^{86} \mathrm{Sr}(0.7028-0.703),{ }^{143} \mathrm{Nd} /{ }^{144} \mathrm{Nd}(0.512949-0.512951)$ and ${ }^{206} \mathrm{~Pb} /{ }^{204} \mathrm{~Pb}(19.292-19.396)$ isotopic compositions (Dupuy et al. 1993). The results have led to the conclusion that their source is uniform isotopically (Dupuy et al. 1993, Bardintzeff et al. 1994). The relatively radiogenic $\mathrm{Pb}$ isotopes associated with unradiogenic $\mathrm{Sr}$ and radiogenic Nd suggest that Fangataufa basalts may have been influenced by a HIMU-like component.

\section{Analytical methods}

\subsection{Major elements}

Major-element concentrations were determined at the Laboratoire Magmas et Volcans (LMV) using Inductively Coupled Plasma Atomic Emission Spectrometry (ICP-AES, Jobin-Yvon ULTIMA C), after alkaline melting with lithium metaborate/tetraborate and nitric acid dissolution. The BHVO-1 reference material was used as an internal standard to determine the reproducibility of the analyses. It is better than $5 \%$ except for $\mathrm{Na}_{2} \mathrm{O}$ and $\mathrm{K}_{2} \mathrm{O}$ (Table SI). Loss on ignition (LOI) was also measured for our samples. Up to $1 \mathrm{~g}$ of sample powder was precisely weighed and subsequently placed in an oven at $110^{\circ} \mathrm{C}$ and $1100^{\circ} \mathrm{C}$ for $24 \mathrm{~h}$ and $48 \mathrm{~h}$ respectively. After cooling down, the sample powders were weighed again and the difference between the masses is the Loss on Ignition.

\subsection{Trace elements}

Up to $300 \mathrm{mg}$ of whole-rock powders were digested using concentrated $\mathrm{HNO}_{3}$ - $\mathrm{HF}-\mathrm{HCl}$ acid mixtures. The fully dissolved samples were evaporated to dryness and re-dissolved in $6 \mathrm{M} \mathrm{HCl}$. Once they were perfectly clear, the samples were split in three aliquots: one for trace element, one for $\mathrm{Sr}$ and $\mathrm{Nd}$ isotopes and finally one for $\mathrm{Cr}$ isotope measurements. For trace-element analyses, an aliquot of $\sim 1$ mg of sample was taken and dried down on the hotplate. The sample was then re-dissovled in $0.05 \mathrm{M}$ 
$\mathrm{HNO}_{3}$ and diluted 2000 times for the inductively coupled plasma mass spectrometer (ICP-MS) measurements. Trace element concentrations were determined using the Agilent 7500 at the LMV. The analyses were standardised against five reference materials (BIR-1, BHVO-2, AGV-1, DNC-1 and W2). Within-run drift was assessed and corrected internally using an In standard. Precision was assessed with repeated measurements of BEN reference material and is routinely better than $4 \%$ ( 2 s.d.).

\subsection{Sr and $\mathrm{Nd}$ isotopes}

An aliquot of the sample solutions, with approximately $1 \mu \mathrm{g}$ of $\mathrm{Nd}$, was dried down and redissolved in $2 \mathrm{ml} 1.25 \mathrm{M} \mathrm{HCl}$. The samples were passed through the column protocol (Sr Spec, True Spec and Ln Spec columns) after most of the iron had been removed through a cation resin (AG50 X4). $\mathrm{Sr}$ and $\mathrm{Nd}$ procedural blanks were negligible with respect to the amount of each element processed through chemistry. All measurements were made on the LMV ThermoFisher Triton Thermo-Ionization Mass Spectrometer (TIMS) with single ( $\mathrm{Sr}$ ) and double (Nd) Re filaments. A typical Sr isotope run consisted of 15 blocks of five cycles ( $8 \mathrm{~s}$ integration time) to allow a full rotation of the virtual amplifier system. Strontium isotope ratios were mass-fractionation corrected with ${ }^{86} \mathrm{Sr} /{ }^{88} \mathrm{Sr}=0.1194$ and normalized to ${ }^{87} \mathrm{Sr} /{ }^{86} \mathrm{Sr}=0.710245$ for the NIST-SRM987 standard. Neodymium isotope measurements consisted of 14 blocks of 10 cycles. Neodymium isotopes were mass-fractionation corrected with ${ }^{146} \mathrm{Nd} /{ }^{144} \mathrm{Nd}=0.7219$ and normalized to ${ }^{143} \mathrm{Nd} /{ }^{144} \mathrm{Nd}=0.512100$ for the JNDi-1 standard. Repeated analyses of the two standards during the course of the study gave ${ }^{87} \mathrm{Sr} /{ }^{86} \mathrm{Sr}=0.710241 \pm 9$ (2 s.d., $\mathrm{n}=$ 13) and ${ }^{143} \mathrm{Nd} /{ }^{144} \mathrm{Nd}=0.512106 \pm 4(2$ s.d., $\mathrm{n}=8)$, in agreement with the long-term reproducibility at LMV i.e., ${ }^{87} \mathrm{Sr} /{ }^{86} \mathrm{Sr}=0.710244 \pm 11(2 \sigma, \mathrm{n}=96)$ and ${ }^{143} \mathrm{Nd} /{ }^{144} \mathrm{Nd}=0.512104 \pm 7(2 \sigma, \mathrm{n}=47)$. The reference material BHVO-2 was also analysed in the same analytical session and gave ${ }^{87} \mathrm{Sr} /{ }^{86} \mathrm{Sr}=$ $0.703469 \pm 5$ ( 2 s.e. $)$ and ${ }^{143} \mathrm{Nd} /{ }^{144} \mathrm{Nd}=0.512977 \pm 3$ (2 s.e.). These values agree with literature values (Weis et al. 2006).

\subsection{Cr isotopes}

Protocols for the separation of $\mathrm{Cr}$ from silicate matrices have been previously published (e.g. Trinquier et al. 2008; Bonnand et al. 2016a). Only a brief summary is given here. Aliquots of $\sim 2 \mu \mathrm{g}$ of 
chromium of the solutions prepared for trace element and $\mathrm{Sr}-\mathrm{Nd}$ isotopes were spiked with the requisite amount of ${ }^{50} \mathrm{Cr}-{ }^{54} \mathrm{Cr}$ double spike (Bonnand et al. 2011). The solutions were dried down and taken up in $6 \mathrm{M} \mathrm{HCl}$ to ensure isotopic equilibrium between the samples and the spike. The protocol used to separate the $\mathrm{Cr}$ fraction from the matrix is a two-column procedure and has been described in details in Bonnand et al. (2016a). Briefly, the first column procedure is designed to remove the major cations while the second column procedure removes the small remaining isobaric interference elements such as Ti. The isotopic measurements were performed on a ThermoFisher Triton TIMS at the Laboratoire Magmas et Volcans. Typical Cr isotope measurements consisted of 54 blocks of 10 cycles. The gains were measured daily and the baselines (30s) were measured before each block. Amplifier rotation was used to cancel out the gain differences between each faraday cups. The external reproducibility obtained for the JP-1 reference material over the course of this study is $\delta^{53} \mathrm{Cr}=-0.108 \pm 0.014 \%$ ( 2 s.d., $\mathrm{n}=8$ ) comparable to previous estimate of this geological reference material (Bonnand et al. 2016a, Li et al. 2016, Zhu et al. 2018).

\section{Results}

The studied samples present relatively limited variations in their major element concentrations. The Fangataufa basalts have high LOI values ranging from 1.4 to $9.9 \%$ (78\% of the samples have LOI values lower than $4 \%$, Table SI), in agreement with previous reported values on samples coming from the same location (Schiano et al. 1990). There is a weak relationship between loss on ignition and $\mathrm{Ca}$ concentration suggesting that interaction with carbonate rocks and/or seawaterderived fluids are responsible for the secondary alteration observed in the samples. In detail, this covariation is strongly dependent on three samples and the absence of correlation between LOI and $\mathrm{Sr}$ isotopes suggest that a simple mixing with carbonate rocks is not the only process at the origin of the high LOI values. Other major element concentrations do not co-vary with LOI and are therefore related to igneous processes. Furthermore, most samples have LOI values between 2 and $4 \%$, which is coherent with submarine emplacement.

Selected major element concentrations, expressed as dry sample, are presented in Table 1 and Figures 1, $\mathrm{S} 1$ and $\mathrm{S} 2$. The $\mathrm{SiO}_{2}$ and $\mathrm{MgO}$ concentrations range from 43.8 to $50.3 \mathrm{wt}$. \% and from 3.7 to 
9.0 wt. $\%$, respectively. The $\mathrm{TiO}_{2}$ concentrations range from 1.8 to 4.3 wt. $\%$. The $\mathrm{K}_{2} \mathrm{O}$ concentrations are more variable and range from 0.1 to $1.8 \mathrm{wt}$. \%. Finally, $\mathrm{CaO}$ concentrations range from $8.2 \mathrm{wt}$. \% to 21.1 wt. \%. Our measurements are in good agreement with previously published results on Fangataufa basalts (Dupuy et al. 1990). Reported in typical TAS diagram (Fig. S1), the studied samples fall in the basalt, picro-basalt, basanite and trachy-basalt fields. Major element compositions show that they have experienced limited magmatic differentiation as previously proposed for Fangataufa. The variations in $\mathrm{K}_{2} \mathrm{O}$ and $\mathrm{TiO}_{2}$ indicate that, in agreement with earlier studies, two magmatic suites have been sampled: one medium to high- $\mathrm{K}$ calc-alcaline $\left(\mathrm{K}_{2} \mathrm{O}>0.75\right.$ wt. $\%, \mathrm{TiO}_{2}>3$ wt. \%) and one low to medium-K calc-alcaline $\left(\mathrm{K}_{2} \mathrm{O}<0.75\right.$ wt. $\%$ and $\left.\mathrm{TiO}_{2}<2.5 \mathrm{Wt} . \%\right)$, hereafter called high-K and low-K suites, respectively. The high-K (red) and low-K (blue) series are shown in Figure 1 and 2. They can be clearly distinguished by their $\mathrm{K}_{2} \mathrm{O}$ content even if a continuum exists.

The minor- and trace-element concentrations measured in Fangataufa basalts are presented in Table S1. Chromium and Th concentrations range from 3.4 to $677.7 \mu \mathrm{g} \mathrm{g}^{-1}$ and from 0.9 to $4.6 \mu \mathrm{g} \mathrm{g}^{-1}$, respectively (Table 1). The $\mathrm{Ni}$ concentrations range from 4.8 to $292.5 \mu \mathrm{g} \mathrm{g}^{-1}$. The $\mathrm{La} / \mathrm{Yb}$ ratio determined for the studied samples varies from 10.0 to 22.8 (Figure 2). While the REE concentrations are positively correlated with $\mathrm{Th}$ concentration, $\mathrm{Cr}$ and $\mathrm{Ni}$ concentrations appear to be negatively correlated to Th content. Our results agree well with previous estimates of the trace element contents of Fangataufa basalts (Schiano et al. 1993).

The $\mathrm{Sr}$ and $\mathrm{Nd}$ isotope data are presented in Table 1 and Figure 3. Fangataufa basalts have $\mathrm{Sr}$ and $\mathrm{Nd}$ isotopic compositions ranging from 0.702865 to 0.703491 and from 0.512883 to 0.512956 , respectively. The results presented in this study are in good agreement with previous studies (Dupuy et al. 1993, Bardintzeff et al. 1994). There is no correlation between $\mathrm{Sr}$ and $\mathrm{Nd}$ isotopes, and between $\mathrm{Sr}$ or $\mathrm{Nd}$ isotopes and LOI. In the case of secondary alteration, Sr isotopes are more readily affected than $\mathrm{Nd}$ isotopes due to the relatively depleted $\mathrm{Nd}$ concentration of authigenic sediments. The discussion will be mainly focus on the $\mathrm{Nd}$ isotopic composition in the following sections.

The $\mathrm{Cr}$ isotopic compositions $\left(\delta^{53} \mathrm{Cr}\right)$ of the studied samples are given in Table 1 and range from -0.226 to $-0.169 \%$. There is no correlation between $\mathrm{Cr}$ isotopes and LOI and other indices of 
alteration. There is a weak relationship between $\mathrm{Cr}$ isotopes and $\mathrm{Cr}$ and $\mathrm{MgO}$ concentrations and $\mathrm{Nd}$ isotopes (Fig. 4 and 5).

\section{Discussion}

5.1. Magmatic processes and the composition of the mantle source

Primary melts produced at the degrees of melting and pressure inferred for OIBs at equilibrium with peridotite have around 12-14\% $\mathrm{MgO}$ (e.g. Laporte et al. 2004). Typical magmas erupting on ocean islands have $\mathrm{MgO}$ concentrations around 7-8\%, representing evolved magmas with substantial olivine crystallisation. Most of Fangataufa rocks have 5-6\% MgO in agreement with such an explanation. A few samples, however, have higher $\mathrm{MgO}$ concentrations (up to 9 wt. \%). These concentrations may reflect either less evolved magmas or olivine accumulation during the magma ascent to the surface, although, in other Ocean Island settings, accumulation of olivine increases the $\mathrm{MgO}$ concentration in magmas up to 25 wt. \% (e.g. La Reunion Island, 26.3\%, Albarède et al. 1997) much higher than the observed variations in Fangataufa basalts. Thus, the relatively small increase in $\mathrm{MgO}$ concentration suggests that accumulation of olivine antecrysts and/or xenocrysts is limited in the studied samples. In modelling the variations of incompatible elements, olivine accumulation is a simple linear addition, whereas fractional crystallisation follows an exponential law. Thus, on a log-log plot of an incompatible element in olivine (e.g. Y) versus a compatible one (e.g. $\mathrm{MgO}$ ), a global covariation with an inflection, corresponding to the composition of the parental liquid, is expected in case of accumulation (e.g. Nebel et al. 2014). In Fangataufa basalts, there is no break in the array (Fig. S6) which suggests that there is indeed limited amount of olivine accumulation.

The $\mathrm{CaO}$ concentration can help us constraining the crystallisation history experienced by the studied samples. The samples with LOI higher than $4.5 \%$ (4 samples) were not considered. In a typical $\mathrm{CaO} / \mathrm{Al}_{2} \mathrm{O}_{3}$ vs $\mathrm{FeO} / \mathrm{MgO}$ plot (Fig. S2), the remaining samples display a negative correlation. This indicates that during magmatic differentiation the fractionating mineralogy assemblage was mainly composed of olivine and clinopyroxene. This observation is similar to that observed for another Ocean Island basalts (La Réunion, Albarède et al. 1997). 
It has been proposed that the source of Fangataufa basalts is relatively homogeneous isotopically compared to other OIBs (Bardintzeff et al. 1994). In contrast, results presented in this study show that although the variations are limited, the studied samples clearly have heterogeneous $\mathrm{Nd}$ isotope ratios. This heterogeneity is not correlated with sample depths and therefore it cannot be linked to the transition from low-K to high-K series. The weak correlation between ${ }^{143} \mathrm{Nd} /{ }^{144} \mathrm{Nd}$ isotopic ratios and $\mathrm{La} / \mathrm{Yb}$ rather suggests that variation of the $\mathrm{Nd}$ composition results from the variation of the degree of partial melting of a heterogeneous source.

Fangataufa basalts plot close to the HIMU end-member region in the ${ }^{143} \mathrm{Nd} /{ }^{144} \mathrm{Nd}$ vs ${ }^{87} \mathrm{Sr} /{ }^{86} \mathrm{Sr}$ isotope variation diagram (Figure 3). The HIMU end-member is classically associated with the recycling of old and altered oceanic crust (i.e., readily-fusible component referred as fertile component) into mantle sources (e.g. Chauvel et al. 1992). The $\mathrm{Sr}$ and $\mathrm{Nd}$ isotope ratios measured in the studied samples together with previous $\mathrm{Pb}$ isotope data (Bardinzeff et al. 1994) suggest the presence of a recycled component in the source of Fangataufa. Along with isotopic evidence for a recycled component in OIBs sources is the Ti concentrations. An elevated Ti concentration in basalts usually reflects the presence of an enriched component in the source (Prytulak and Elliot 2007). It is indeed difficult to produce high $\mathrm{TiO}_{2}$ concentration in silicate melt when melting typical peridotite composition (garnet or spinel). The Fangataufa basalts have $\mathrm{TiO}_{2}$ concentrations ranging from 1.8 to 4.3 wt. $\%$ with an average of 3.17 wt. \% in line with other OIBs (Prytulak and Elliot 2007). The high Ti concentration in the basalts analysed in this study, together with their isotopic compositions, indicates that the source of these basalts has been enriched by a "fertile" component. The presence of a "fertile" component in the source of Fangataufa basalts has a strong implication for the behaviour of incompatible trace elements during partial melting.

\subsection{The influence of partial melting on the trace element budget}

The studied samples show large variations of their trace element concentrations. Fangataufa basalts have REE patterns enriched in Light REE (LREE) and depleted in Heavy REE (HREE), like typical OIBs (Fig. S3). The $\mathrm{La} / \mathrm{Yb}$ ratio varies from 7.2 to 16.4 in our less altered samples compared to 1.5 in the primitive mantle (Sun and McDonough 1995). Variations in REE concentrations can be 
explained by two igneous processes: partial melting and fractional crystallisation. The positive

312

313 correlation defined by our samples between REE (and also La/Yb) and Th (a strongly incompatible element) indicates that the observed variations are mainly due to partial melting. It is also confirmed by the positive correlation between $\mathrm{Th} / \mathrm{Nd}$ ratio and Th concentration for the studied samples.

A model for the partial melting of a mantle source is presented in Figure 6. In order to fractionate the $\mathrm{La} / \mathrm{Yb}$ ratio and also to explain the $\mathrm{Nd}$ isotopic composition of basalts (section 5.1), we considered a uniform mixed source composed of $2 \%$ "fertile" component and $98 \%$ of a peridotite in the garnet stability field (a spinel peridotite would not explain the high $\mathrm{La} / \mathrm{Yb}$ values). The partition coefficients and the initial concentrations used in the model are presented in Table 2. Hirschmann and Stolper (1996) reported a difference in productivity between "fertile" component and peridotite during partial melting. Based on their experimental results, we assigned to the "fertile" component a productivity four times higher than that of the peridotite. The mineralogy of the peridotite was set to $57 \%$ olivine (ol), $13 \%$ clinopyroxene (cpx), $28 \%$ orthopyroxene (opx) and 5\% garnet (gt), similarly to the mineralogy used by Putirka et al. (2011). The modal compositions of pyroxenites are extremely variable (e.g. Lambart et al. 2016). In this study, we considered an "eclogite type" component with a mineralogy of $40 \%$ cpx, 60\% gt (e.g. Sossi and O'Neill 2017). As melting of the mantle is non-modal, the effect of melting stoichiometry on the partition coefficient has to be considered (e.g. Shaw 1970, Sossi and O’Neill 2017, Shen et al. 2018). The melting reactions used in our model are $0.05^{*} \mathrm{Ol}+$ $0.96 * \mathrm{Cpx}+0.14 * \mathrm{Gt}=0.15^{*} \mathrm{Opx}+1 * \mathrm{Liq}$ for the garnet peridotite and $0.8 * \mathrm{Cpx}+0.2 * \mathrm{Gt}=1 * \mathrm{Liq}$ for the "fertile" component (Walters 2003, Sossi and O'Neill 2017). At 1\% partial melting, the Th concentration in the melt is $8.5 \mu \mathrm{g} \mathrm{g}^{-1}$ and the $\mathrm{La} / \mathrm{Yb}$ ratio is 44 . At $10 \%$ partial melting, the $\mathrm{Th}$ concentration is $0.86 \mu \mathrm{g} \mathrm{g}^{-1}$ and the $\mathrm{La} / \mathrm{Yb}$ ratio is 5.6. The model reproduces the $\mathrm{Th}$ and $\mathrm{La} / \mathrm{Yb}$ variations observed in Fangataufa basalts with a degree of partial melting varying from $2 \%$ to $10 \%$. We therefore propose that the high-K series is produced by $2-5 \%$ partial melting of such a mixed mantle source, whereas the low-K series was produced by up to $10 \%$ partial melting. Our model allows us to reproduce the variations in trace element concentrations and also the small variations in $\mathrm{Nd}$ isotopes if we modify the difference of productivity between the "fertile" and peridotite components with partial melting. As melting proceeds, the "fertile" component is melting first but becomes progressively diluted 
by melts derived from the garnet peridotites (with higher $\varepsilon^{143} \mathrm{Nd}$ ). Importantly, the change in fertility would not significantly change the main observation obtained with our conceptual non-modal melting model of a mixed source presented in Figure 7. Fangataufa basalts are produced by partial melting of a mixed source (garnet peridotite and a fertile component) with the high-K series produced with lower degree of partial melting compared to the low-K series.

\subsection{Variations in $\mathrm{Cr}$ concentration: partial melting vs fractional crystallisation}

Contrary to most trace elements, the variations in $\mathrm{Cr}$ and $\mathrm{Ni}$ contents do not positively correlate with $\mathrm{Th}$ and/or $\mathrm{La} / \mathrm{Yb}$ ratio (Fig. 7 and $\mathrm{S} 4$ ). As it is typically admitted that Th is an ultra-incompatible element with a $\mathrm{D}^{\mathrm{Th}}$ crystal-melt close to 0 (e.g. McKenzie and O’Nions 1995), this indicates that $\mathrm{Cr}$ behaviour is not controlled by partial melting but is strongly affected by another igneous process. During fractional crystallisation of phases such as chromite $\left(\mathrm{D}^{\mathrm{Cr}}\right.$ chromite-melt $=170$, Liu and O'Neill 2004), $\mathrm{Cr}$ behaves as a compatible element and so its concentration decreases rapidly in the residual silicate melt. It is therefore possible to explain the variations measured in Fangataufa basalts by fractional crystallisation of Cr-bearing phases early in the crystallisation sequence. Turning to nickel, it also behaves compatibly during igneous processes and is compatible into olivine (e.g. $\mathrm{D}^{\mathrm{Ni}}$ olivine-melt $=9.4$, McKenzie and O'Nions 1995), one of the early phases to crystallise from a basaltic melt. The Ni behaviour in basaltic system is strongly dependent on melt composition and temperature (e.g. Matzen et al. 2013). The positive correlation between $\mathrm{Cr}$ and $\mathrm{Ni}$ (slope of 2.7, Fig. S5) shows that both elements are affected during the crystallisation of the parental melts.

The behaviour of chromium in basaltic systems has attracted a lot of interest. It is however difficult to model its behaviour in the presence of spinel because $\mathrm{Cr}$ is highly compatible in this mineral and therefore its presence controls the way chromium will be partitioned between the solid and the silicate melt. The solubility of chromium in silicate melts has been extensively studied and, in the presence of spinel, the main factors controlling the $\mathrm{Cr}$ concentration in the melts are temperature and oxygen fugacity (Hanson and Jones, 1998, Roeder and Reynolds 1991). In general, lower temperature favours $\mathrm{Cr}^{3+}$ in the silicate melts as does higher $f \mathrm{O}_{2}$ ( $\mathrm{Li}$ et al. 1995). At fixed $f \mathrm{O}_{2}$, a decrease in temperature is associated with a decrease in the saturated $\mathrm{Cr}$ concentration in the silicate melts (e.g. 

concentration in silicate melt vary from $\sim 3000 \mu \mathrm{g} \mathrm{g}-1$ at $1450^{\circ} \mathrm{C}$ to $\sim 300 \mu \mathrm{g} \mathrm{g}^{-1}$ at $1200{ }^{\circ} \mathrm{C}$ (Murck and Campbell 1986). Importantly, the $\mathrm{Cr}^{3+} / \mathrm{Cr}_{\mathrm{TOT}}$ ratio in natural basalts are unknown due to the reaction $\mathrm{Fe}^{3+}+\mathrm{Cr}^{2+}=\mathrm{Fe}^{2+}+\mathrm{Cr}^{3+}$ that happens during quenching (Berry et al. 2004). Depending on the physical conditions during melting, the $\mathrm{Cr}$ concentration in silicate melts can vary from $5000 \mu \mathrm{g} \mathrm{g}^{-1}$ (lunar basalts) to $500 \mu \mathrm{g} \mathrm{g}^{-1}$ (MORB). If initial melts in Fangataufa have formed in typical upper mantle conditions $\left(f \mathrm{O}_{2}=\mathrm{QFM} \pm 1\right.$ and $\left.\mathrm{T}=1300^{\circ} \mathrm{C}\right)$, we could have assumed that regardless of partial melting the $\mathrm{Cr}$ concentration is between 500 and $600 \mu \mathrm{g} \mathrm{g}^{-1}$. However, our Th-REE modelling shows that partial melting happened in the garnet stability field. Using garnet as a phase residue during melting implies that the overall $\mathrm{D}$ decreases. As a consequence, the $\mathrm{Cr}$ concentration in the parental melt is controlled by the partition coefficient of $\mathrm{Cr}$ between garnet, clinopyroxene and orthopyroxene and the silicate melt (Table 2), and this results in a concentration of Cr slightly higher in the primary melts, between 630 and $700 \mu \mathrm{g} \mathrm{g}^{-1}$.

The models presented in Figures 7 and S4 combine partial melting of a mixed mantle source (peridotite + "fertile" component) and fractional crystallisation of olivine, clinopyroxene and spinel. During partial melting, the average D values between crystals and melt for $\mathrm{Cr}$ and $\mathrm{Ni}$ are 5.5 and 8.5, respectively (Table 2). Thus, the $\mathrm{Cr}$ and $\mathrm{Ni}$ concentrations in the primary melts vary little with changing degree of partial melting: as stated above, the concentration of $\mathrm{Cr}$ in the melt ranges from 630 to 700 $\mu \mathrm{g} \mathrm{g}^{-1}$, whereas the concentration of $\mathrm{Ni}$ is buffered by the presence of olivine in the source and is about $200 \mu \mathrm{g} \mathrm{g}^{-1}$. For fractional crystallisation, we assume it happened at low pressure and we consider a crystallizing assemblage composed of olivine (50\%), clinopyroxene (45\%) and spinel (5\%). The large variations in $\mathrm{Cr}$ and $\mathrm{Ni}$ concentrations can be then explained by up to $30 \%$ fractional crystallisation. In this model, during crystallisation the Cr budget is 58\% in spinel, $37 \%$ in cpx and 5\% in olivine. It has to be mentioned that values for $\mathrm{Cr}$ partition coefficients available in the literature are strongly variable and therefore this can affect the models presented in this study. It is especially true for clinopyroxene and spinel with experimentally determined partition coefficients varying over one order of magnitude (e.g. Hauri et al. 1994, Liu and O’Neill 2004, Mallmann and O’Neill 2009). However, the main conclusions reached in this discussion would not change. 

contents measured in Fangataufa basalts as opposed to incompatible elements. Modelling shows that fractional crystallisation of a Cr-bearing phases (clinopyroxene and spinel) and olivine is the main process controlling the behaviour of chromium. Moreover, the melts produced by low degree of partial melting are also characterised by more evolved liquid in term of fractional crystallisation. observed variations are small which suggests that igneous processes have a limited impact on the $\mathrm{Cr}$ isotopic composition of terrestrial basalts. First, it is important to note that there is no correlation between $\mathrm{Cr}$ isotopes and LOI which indicates that the processes responsible for the high LOI values in Fangataufa basalts do not affect their Cr isotopic compositions. We therefore argue that the observed variations in $\mathrm{Cr}$ isotopes are due to igneous processes. The samples with high $\mathrm{MgO}$ have on average a heavier isotopic composition and the samples with less $\mathrm{Cr}$ have on average a lighter $\mathrm{Cr}$ isotopic composition compared to $\mathrm{Cr}$ rich samples. As explained above, the variations in $\mathrm{Cr}$ and $\mathrm{MgO}$ concentrations can be explained by a variation in the rate of fractional crystallisation during magmatic differentiation. In Figure 8, we present a Rayleigh fractionation model to reproduce the small but nonetheless resolvable $\mathrm{Cr}$ isotopic variations. For the low-K series, we assume an initial $\mathrm{Cr}$ concentration and isotopic composition of $670 \mu \mathrm{g} \mathrm{g}^{-1}$ and $-0.18 \%$, respectively. The initial $\mathrm{Cr}$ concentration was obtained from the modelling done in Figure 7, where we calculated the $\mathrm{Cr}$ concentration in the silicate liquid at equilibrium with a mixed source (98\% garnet peridotite and $2 \%$ "fertile" component) at 7\% partial melting. We decided to use the average of the Cr-rich samples (> $500 \mu \mathrm{g} \mathrm{g}^{-1}$ ) as a starting point in the model with an isotopic composition of $-0.18 \pm 0.02 \%$. The variations observed can be modelled with a Rayleigh fractionation model with a bulk isotopic fractionation $\left(\Delta^{53} \mathrm{Cr}_{\text {melt-crystals }}\right)$ of $-0.010 \pm 0.005 \%$ (Fig. 8). For the high-K series, the initial $\mathrm{Cr}$ concentration is more difficult to constrain. If the high-K series has the same modal proportion in the source as the low-K series, then its initial Cr concentration is likely to be very similar. In this case, assuming the same initial $\delta^{53} \mathrm{Cr}$, the $\mathrm{Cr}$ isotopic composition in the high-K series can be modelled with 
423 a fractionation factor $\left(\Delta^{53} \mathrm{Cr}_{\text {melt-crystals }}\right)$ of $-0.020 \pm 0.010 \%$, slightly higher than that of the low-K series.

424 If the initial $\mathrm{Cr}$ concentration in the high-K series was lower than the low-K series because of a change in the bulk partition coefficient between the residue and the melt, then the fractionation factor needed to explain the observed variations would be even higher. lunar basalts. In Figure 8, we also consider a fractional crystallisation model for the lunar basalts. This model shows that the isotopic fractionation $\left(\Delta^{53} \mathrm{Cr}_{\text {melt-crystals }}=-0.07 \%\right)$ for the lunar samples is higher than that of Fangataufa basalts. This difference can have several origins. First, the mineralogy of the crystallising assemblage may be different in both terrestrial and lunar conditions. As described above, clinopyroxene is a major component of the crystallising assemblage in terrestrial basalts, and in the models presented in Figure 7, $\mathrm{Cr}$ in cpx accounts for about $\sim 50 \%$ of total $\mathrm{Cr}$. Clinopyroxene has a lighter isotopic composition compared to chromite (Shen et al. 2018) and crystallising large amount of cpx will decrease the bulk fractionation factor between melt and crystals. The second option is linked to the fact that the redox conditions on the Moon and the Earth are very different. $\mathrm{The}^{\mathrm{Cr}^{3+}}$ concentration in the silicate melts is mainly controlled by two equilibria: (i) the homogeneous equilibrium $\mathrm{CrO}+1 / 4$ $\mathrm{O}_{2}=\mathrm{CrO}_{1.5}$ and (ii) chromite saturation (e.g. $2 \mathrm{CrO}_{1.5}+\mathrm{MgO}=\mathrm{MgCr}_{2} \mathrm{O}_{4}$ ). In lunar conditions (reduced), $\mathrm{Cr}$ is believed to be mainly $\mathrm{Cr}^{2+}$ (Sutton et al. 1995) and the $\mathrm{Cr}^{3+} / \mathrm{Cr}_{\mathrm{TOT}}$ ratio is much lower in lunar basalts $(0.1$ at IW-1) than in terrestrial basalts (0.6-0.7 at QFM). It is likely that the bulk fractionation factor during fractional crystallisation is controlled by the difference in $\mathrm{Cr}^{3+} / \mathrm{Cr}_{\mathrm{TOT}}$ ratio between the melts and the crystallising phases. On the Moon, there is a considerable difference between $\mathrm{Cr}^{3+} / \mathrm{Cr}_{\mathrm{TOT}}$ ratio in the melt $\left(\mathrm{Cr}^{3+} / \mathrm{Cr}_{\mathrm{TOT}}=0.1\right)$ and the crystallising phases (e.g. $\mathrm{Cr}^{3+} / \mathrm{Cr}_{\mathrm{TOT}}=1$ in chromite) which result in larger isotopic shifts. Under terrestrial conditions, the difference in $\mathrm{Cr}^{3+} / \mathrm{Cr}_{\mathrm{TOT}}$ between silicate melts and crystallising phases is smaller resulting in limited $\mathrm{Cr}$ isotopic variations.

It has been proposed in the literature that $\mathrm{Cr}$ isotopes are fractionated during partial melting of the mantle (Xia et la. 2017, Shen et al. 2018). While partial melting proceeds, the residue would become isotopically heavier. Accordingly, the isotopic composition of silicate melts at equilibrium with 
mantle peridotites (that is to say, primary melts) should be isotopically lighter compare to their sources.

452 The difficulty, however, is to determine the $\mathrm{Cr}$ isotopic composition of the primary melts. In order to determine the $\mathrm{Cr}$ isotopic composition of the parental melt of Fangataufa basalts, we consider the average of the Cr-rich samples analysed in this study. The obtained value (Cr isotopic composition of $\left.\delta^{53} \mathrm{Cr}=-0.18 \pm 0.02 \%(2 \mathrm{sd}, \mathrm{n}=3)\right)$ is on the low end of the BSE values of $\delta^{53} \mathrm{Cr}=-0.12 \pm 0.10 \%$ o (Schoenberg et al. 2008) and $\delta^{53} \mathrm{Cr}=-0.11 \pm 0.06 \%$ (Sossi et al. 2018). Interestingly, it is lighter than most $\mathrm{Cr}$ isotopic composition reported for mantle xenoliths. This observation confirms that $\mathrm{Cr}$ isotopes are fractionated during low degree partial melting in mantle conditions and that the melts are enriched in light $\mathrm{Cr}$ isotopes compared to the source. Using our primary $\mathrm{Cr}$ isotopic composition and the BSE value of Sossi et al. 2018, we propose a bulk fractionation factor $\left(\Delta^{53} \mathrm{Cr}_{\text {melt-residue }}\right)$ during low-degree partial melting of $-0.07+0.06 \%$. This fractionation is small and cannot solely explain the large $\mathrm{Cr}$ isotopic variations reported in mantle xenoliths $\left(-0.51<\delta^{53} \mathrm{Cr}<0.74 \%\right.$, Xia et al. 2017). Assuming an isotopic fractionation of $\Delta^{53} \mathrm{Cr}_{\text {melt-residue }}$ of $-0.07 \%\left(\Delta^{53} \mathrm{Cr}_{\text {melt-residue }}=\delta^{53} \mathrm{Cr}_{\text {melt }}-\delta^{53} \mathrm{Cr}_{\text {residue }}\right)$, partial melting of the mantle can only explain up to $0.05 \%$ variations in mantle xenoliths. As stated by Shen et al. (2018), the variations caused by partial melting is small compared to the reported $1.2 \%$ variations in mantle xenoliths (Xia et al. 2017).

It has been previously proposed that the fractionation factor between the residues and products of partial melting changes with the degree of partial melting (Shen et al. 2018). Interestingly, Fangataufa basalts form two distinct groups in $\delta^{53} \mathrm{Cr}-\mathrm{Nd}$ isotope space (Fig. 5). We have previously proposed that the variations in $\mathrm{Nd}$ isotopes reflect a difference in productivity between the "fertile" and peridotite components with partial melting. Indeed, the correlation between $\mathrm{Nd}$ isotopes and $\mathrm{La} / \mathrm{Yb}$ ratio suggests that low degree of partial melting is associated with less radiogenic $\mathrm{Nd}$ isotopic composition. At face value, the covariation between $\mathrm{Cr}$ and $\mathrm{Nd}$ isotopes could be explained by a change in the fractionation factor between products and residues during partial melting. This finding would agree with the model proposed by Shen et al. (2018) performed with spinel peridotite. However, the shift in Cr isotopic composition between the high-K and the low-K series is opposite to what the model predicts. Using the Shen et al. (2018) model and assuming the same initial Cr isotopic composition for the source, it can be shown that melts produced at low degree of partial melting should be isotopically heavier than melts 
produced at higher degree of melting. Instead, our results show that melts produced by low degree of partial melting have lighter $\mathrm{Cr}$ isotopic composition because the $\mathrm{Cr}$ isotopic composition of the high-K series is lighter compare to the low-K series.

It is however important to note that the samples with less radiogenic $\mathrm{Nd}$ isotopic composition have experienced more fractional crystallisation than the melts produced by higher degrees of partial melting. Indeed, as described above, the samples with high $\mathrm{Th}$ and/or $\mathrm{La} / \mathrm{Yb}$ ratios have lower $\mathrm{Cr}$ and Ni concentrations. It is therefore possible that the covariation between $\mathrm{Cr}$ and $\mathrm{Nd}$ isotopes is due to the fact that samples with lower degrees of partial melting are more evolved basalts and the lighter $\mathrm{Cr}$ isotopic composition is due to fractional crystallisation rather than a change in the rate of partial melting. This is supported by the similar isotopic composition between the samples with the highest $\mathrm{Cr}$ concentration in each suite. The difficulty with determining the initial $\mathrm{Cr}$ concentration in the high- $\mathrm{K}$ series do not allow us to say whether partial melting or fractional crystallisation are responsible for the grouping between the high- $\mathrm{K}$ and the low-K series in the $\mathrm{Nd}$ vs $\mathrm{Cr}$ isotopes plot. More work is needed to test this hypothesis. It is also interesting to note that until the mechanisms responsible for the fractionation during partial melting are better understood it is impossible to reconstruct the $\mathrm{Cr}$ isotopic composition of terrestrial reservoirs using melts produced by partial melting of the mantle.

\section{Conclusions}

We have investigated the $\mathrm{Cr}$ isotopes behaviour during igneous processes. To this end, 21 samples from Fangataufa Island were measured for their major and trace elements concentrations, $\mathrm{Sr}$ and $\mathrm{Nd}$ isotopic composition and finally for their $\mathrm{Cr}$ isotopic composition. Fangataufa basalts are characterised by relatively small variations in major elements but two series are identified (low-K and high-K) based on their $\mathrm{K}_{2} \mathrm{O}$ and $\mathrm{TiO}_{2}$ concentrations. The major element concentrations also indicate that Fangataufa samples have experience some magmatic differentiation and that both olivine and clinopyroxene crystalized.

The variations in incompatible trace element content (e.g. REE, Th) in Fangataufa basalts can be explained by changes in degree of partial melting of the mantle source. The variations in $\mathrm{La} / \mathrm{Yb}$ ratio indicate that the melting producing Fangataufa basalts happened in the garnet stability field. The 
variations in $\mathrm{Nd}$ isotopes suggest that the mantle source is heterogeneous and composed of a peridotite and a small amount of "fertile" component. The variations in compatible elements such as $\mathrm{Cr}$ and $\mathrm{Ni}$ in Fangataufa basalts can be explained by fractional crystallisation of olivine, clinopyroxene and chromite. The models presented in this study suggest that relatively small amount of crystallisation can explain the large range of variation in $\mathrm{Cr}$ and $\mathrm{Ni}$ concentrations measured in natural samples.

Fangataufa basalts are characterised by variations in Cr isotopes from -0.23 to $-0.17 \%$. Overall, the Cr-rich samples have heavier $\mathrm{Cr}$ isotopic composition compared to $\mathrm{Cr}$-poor samples. The small but nonetheless distinguishable variations in $\mathrm{Cr}$ isotopes are better explained by fractional crystallisation. The low-K and high-K suites can be modelled with fractionation factors $\left(\Delta^{53} \mathrm{Cr}_{\text {melt-residue }}\right)$ of $-0.010 \pm$ $0.005 \%$ and $-0.020 \pm 0.010 \%$, respectively. Compared to the lunar basalts, the isotopic fractionation between the melt and the crystallising phases is smaller in terrestrial samples and two hypotheses could explain this observation. The mineralogy with chromite (on the Moon) to clinopyroxene + chromite in the studied setting could change the bulk isotopic fractionation and possibly the more oxidised conditions on Earth could also limit the fractionation factor. Finally, the more primitive basalts have slightly lower $\mathrm{Cr}$ isotopic composition compared to mantle xenoliths suggesting that $\mathrm{Cr}$ isotopes are fractionated during partial melting with the melts being lighter than the residues. However, the small difference between basalts and mantle xenolith cannot explain the large variations observed in mantle xenoliths. The covariation between $\delta^{53} \mathrm{Cr}$ and $\varepsilon^{143} \mathrm{Nd}$ values in Fangataufa basalts can be explained by two processes: (i) lower degree of partial melting have lighter $\mathrm{Cr}$ isotopic composition and (ii) melts produced by low degree of partial melting have also experienced more fractional crystallisation.

(1)

. 
References:

Albarède, F., Luais, B., Fitton, G., Semet, M., Kaminski, E., Upton, B.G.J., Bachèlery, P., Cheminée, J.L., 1997. The Geochemical Regimes of Piton de la Fournaise Volcano (Réunion) During the Last 530000 Years, Journal of Petrology 38, 171-201. https://dx.doi.org/10.1093/petroj/38.2.171.

Allegre, C., Manhes, G., Lewin, E., 2001. Chemical composition of the Earth and the volatility control on planetary genetics. Earth Planet. Sci. Lett. 185, 49-69. https://doi.org/10.1016/S0012821X(00)00359-9

Allegre, C.J., Poirier, J.P., Humler, E., Hofmann, A.W., 1995. The chemical - composition of the Earth. Earth Planet. Sci. Lett. 134, 515-526. https://doi.org/10.1016/0012-821X(95)00123-T

Bardintzeff, J., Leyrit, H., Guillou, H., Guille, G., Bonin, B., Giret, A., Brousse, R., 1994. Transition Petrographical between and evidence alkali from basalts : geochemical 28.

Berry, A.J., O'Neill, H.S.C., 2004. A XANES determination of the oxidation state of chromium in silicate glasses. Am. Mineral. 89, 790-798.

Berry, A.J., O’Neill, H.S.C., Scott, D.R., Foran, G.J., Shelley, J.M.G., 2006. The effect of composition on $\mathrm{Cr} 2+/ \mathrm{Cr} 3+$ in silicate melts. Am. Mineral. 91, 1901-1908. https://doi.org/10.2138/am.2006.2097

Bonnand, P., Halliday, A.N., 2018. Oxidized conditions in iron meteorite parent bodies. Nat. Geosci. 11, 401-405. https://doi.org/10.1038/s41561-018-0128-2

Bonnand, P., Parkinson, I.J., Anand, M., 2016. Mass dependent fractionation of stable chromium isotopes in mare basalts: Implications for the formation and the differentiation of the Moon. Geochim. Cosmochim. Acta 175, 208-221. https://doi.org/10.1016/j.gca.2015.11.041

Bonnand, P., Parkinson, I.J., James, R.H., Karjalainen, A.-M., Fehr, M.A., 2011. Accurate and precise determination of stable $\mathrm{Cr}$ isotope compositions in carbonates by double spike MC-ICP-MS. J. Anal. At. Spectrom. 26, 528-535. https://doi.org/10.1039/c0ja00167h

Bonnand, P., Williams, H.M., Parkinson, I.J., Wood, B.J., Halliday, A.N., 2016. Stable chromium isotopic composition of meteorites and metal-silicate experiments: Implications for fractionation during core formation. Earth Planet. Sci. Lett. 435, 14-21. https://doi.org/10.1016/j.eps1.2015.11.026

Chauvel, C., Hofmann, A.W., Vidal, P., 1992. HIMU-EM: The French Polynesian connection. Earth Planet. Sci. Lett. 110, 99-119. https://doi.org/10.1016/0012-821X(92)90042-T

Clesi, V., Bouhifd, M.A., Bolfan-Casanova, N., Manthilake, G., Fabbrizio, A., Andrault, D., 2016. Effect of $\mathrm{H}_{2} \mathrm{O}$ on metal-silicate partitioning of Ni, Co, V, Cr, Mn and Fe: Implications for the oxidation state of the Earth. Geochim. Cosmochim. Acta 192, 97-121. https://doi.org/10.1016/j.gca.2016.07.029

Dauphas, N., Roskosz, M., Alp, E.E., Neuville, D.R., Hu, M.Y., Sio, C.K., Tissot, F.L.H., Zhao, J., Tissandiere, L., Medard, E., Cordier, C., 2014. Magma redox and structural controls on iron isotope 
variations in Earth's mantle and crust. Earth Planet. Sci. Lett. 398, 127-140. https://doi.org/10.1016/j.epsl.2014.04.033

Dupuy, C., Vidal, P., Maury, R.C., Guille, G., 1993. Basalts from Mururoa, Fangataufa and Gambier islands (French Polynesia): Geochemical dependence on the age of the lithosphere. Earth and Planet. Sci. Lett. 117, 89-100.

Farkas, J., Chrastny, V., Novak, M., Cadkova, E., Pasava, J., Chakrabarti, R., Jacobsen, S.B., Ackerman, L., Bullen, T.D., 2013. Chromium isotope variations $(\delta 53 / 52 \mathrm{Cr})$ in mantle-derived sources and their weathering products: Implications for environmental studies and the evolution of 853/52Cr in the Earth's mantle over geologic time. Geochim. Cosmochim. Acta 123, 74-92. https://doi.org/10.1016/j.gca.2013.08.016

Gale, A., Dalton, C.A., Langmuir, C.H., Su, Y., Schilling, J.G., 2013. The mean composition of ocean ridge basalts. Geochemistry, Geophys. Geosystems 14, 489-518. https://doi.org/10.1029/2012GC004334

Guillou, H., Guille, G., Brousse, R., Bardintzeff, J-M. 1990. Evolution de basaltes tholéitiques vers des basaltes alcalins dans le substratum volcanique de Fangataufa (Polynésie Francaise). Bull Soc. géol. France, 8, VI, n³, 537-549.

Hanson, B., Jones, J.H., 1998. The systematics of Cr3+ and Cr2+ partitioning between olivine and liquid in the presence of spinel. Am. Mineral. 83, 669-684.

Hirschmann, M.M., Stolper, E.M., 1996. A possible role for garnet pyroxenite in the origin of the "garnet signature" in MORB. Contrib. to Mineral. Petrol. 124, 185-208. https://doi.org/10.1007/s004100050184

Hofmann, A.W., 2007. Sampling mantle heterogeneity through oceanic basalts: isotopes and trace elements. Treatise on Geochemistry, Volume 2. Editor: Richard W. Carlson. Executive Editors: Heinrich D. Holland and Karl K. Turekian. pp. 568. Elsevier.

Javoy, M., Kaminski, E., Guyot, F., Andrault, D., Sanloup, C., Moreira, M., Labrosse, S., Jambon, A., Agrinier, P., Davaille, A., Jaupart, C., 2010. The chemical composition of the Earth: Enstatite chondrite models. Earth Planet. Sci. Lett. 293, 259-268. https://doi.org/10.1016/j.eps1.2010.02.033

Kang, J.-T., Ionov, D.A., Liu, F., Zhang, C.-L., Golovin, A. V, Qin, L.-P., Zhang, Z.-F., Huang, F., 2017. Calcium isotopic fractionation in mantle peridotites by melting and metasomatism and $\mathrm{Ca}$ isotope composition of the Bulk Silicate Earth. Earth Planet. Sci. Lett. 474, 128-137. https://doi.org/10.1016/j.eps1.2017.05.035

Lambart, S., Baker, M.B., Stolper, E.M., 2016. The role of pyroxenite in basalt genesis: Melt-PX, a melting parametization for mantle pyroxenites between 0.9 and 5GPa. J. Geophys. Res. Solid Earth, 121, 5708-5735, doi:10.1002/2015JB012762. 
Laporte, D., Toplis, M.J., Seyler, M., Devidal, J.L., 2004. A new experimental technique for extracting liquids from peridotite at very low degrees of melting: application to partial melting of depleted peridotite. Contrib. to Mineral. Petrol. 146, 463-484.

Li, C.F., Feng, L.J., Wang, X.C., Chu, Z.Y., Guo, J.H., Wilde, S.A., 2016. Precise measurement of Cr isotope ratios using a highly sensitive $\mathrm{Nb} 2 \mathrm{O} 5$ emitter by thermal ionization mass spectrometry and an improved procedure for separating Cr from geological materials. J. Anal. At. Spectrom. 31, 23752383. https://doi.org/10.1039/c6ja00265j

Li, J.P., O'Neill, H.S.C., Seifert, F., 1995. Subsolidus phase-relations in the system MgO-SiO2-CrO in equilibrium with metallic $\mathrm{Cr}$, and their significance for the petrochemistry of chromium. J. Petrol. 36, 107-132. https://doi.org/10.1093/petrology/36.1.107

Liang, Y. and Elthon, D. 1990. Evidence from chromium abundancies in mantle rocks for extraction of picrate and komatiite melts. Nature 343, 551-553.

Liu, X., O'Neill, H.S.C., 2004. The effect of Cr2O3 on the partial melting of spinel lherzolite in the system $\mathrm{CaO}-\mathrm{MgO}-\mathrm{Al} 2 \mathrm{O} 3-\mathrm{SiO} 2-\mathrm{Cr} 2 \mathrm{O} 3$ at 1.1 GPa. J. Petrol. 45, 2261-2286. https://doi.org/10.1093/petrology/egh055

Lodders, K., 2003. Solar system abundances and condensation temperatures of the elements. Astrophys. J. 591, 1220-1247. https://doi.org/10.1086/375492

Mallmann, G., and O'Neill, H., 2009. The crystal/melt partitioning of V during mantle melting as a function of oxygen fugacity compared with some other elements (Al, P, Ca, Sc, Ti, Cr, Fe, Ga, Y, $\mathrm{Zr}$ and $\mathrm{Nb})$. J. Petrol. 50, 1765-1794.

Matzen, A.K., Wood, B.J., Baker, M.B., Stolper, E.M., 2013. The temperature and pressure dependence of nickel partitioning between olivine and silicate melt. J. Petrol. 54 (12), 2521-2545.

McDonough, W.F., 2013. Compositional Model for the Earth's Core, 3rd ed, Treatise on Geochemistry: Second Edition. Elsevier Ltd. https://doi.org/10.1016/B978-0-08-095975-7.00215-1

McDonough, W.F., Sun, S.S., 1995. The composition of the Earth. Chem. Geol. 120, 223-253. https://doi.org/10.1016/0009-2541(94)00140-4

Mckenzie, D., O’nions, R.K., 1995. The source regions of ocean island basalts. J. Petrol. 36, 133-159. https://doi.org/10.1093/petrology/36.1.133

Murck, B., and Campbell, I.H., 1986. The effects of temperature, oxygen fgacity and melt composition on the behaviour of chromium in basic and ultrabasic melts. Geochim. Cosmochim. Acta 50, 18711887.

Nebel, O., Campbell, I.H., Sossi, P., Van Kranendonk, M.J., 2014. Hafnium and iron isotopes in early Archean komatiites record a plume-driven convection cycle in the Hadean Earth. Earth Planet. Sci. Lett. 397, 111-120.

Palme, H., and O'Neill, H., 2013. Cosmochemical Estimates of Mantle Composition, Treatise on Geochemistry: Second Edition, Publisher: Elsevier Inc. 3, 1-39. 
Papike, J.J., Karner, J.M., Shearer, C.K., 2005. Comparative planetary mineralogy: Valence state partitioning of $\mathrm{Cr}, \mathrm{Fe}, \mathrm{Ti}$, and $\mathrm{V}$ among crystallographic sites in olivine, pyroxene, and spinel from planetary basalts. Am. Mineral. 90, 277-290. https://doi.org/10.2138/am.2005.1779

Prytulak, J., Elliott, T., 2007. $\mathrm{TiO}_{2}$ enrichment in ocean island basalts. Earth Planet. Sci. Lett. 263, 388403.

Putirka, K., Ryerson, F.J., Perfit, M., Ridley, W.I., 2011. Mineralogy and composition of the oceanic mantle. J. Petrol. 52, 279-313. https://doi.org/10.1093/petrology/egq080

Roeder, P.L., Reynolds, I., 1991. Crystallization of chromite and chromium solubility in basaltic melts. J. Petrol. 32, 909-934. https://doi.org/10.1093/petrology/32.5.909

Schiano, P., Guille, G., Léotot, C., Brousse, R., 1990. Mise en évidence de cycles dans les produits volcaniques aériens et sub-aériens de l'atoll de Fangataufa (Plynésie francaise). C.R. Acad. Sci. Paris, 311, Série II, 1521-1527.

Schiano, P., Dupré, B., Lewin, E., 1993. Application of element concentration variability to the study of basalt alteration (Fangataufa atoll, French Polynesia). Chem. Geol. 104, 99-124. https://doi.org/10.1016/0009-2541(93)90145-9

Schoenberg, R., Merdian, A., Holmden, C., Kleinhanns, I.C., Haßler, K., Wille, M., Reitter, E., 2016. The stable $\mathrm{Cr}$ isotopic compositions of chondrites and silicate planetary reservoirs. Geochim. Cosmochim. Acta 183, 14-30. https://doi.org/10.1016/j.gca.2016.03.013

Schoenberg, R., Zink, S., Staubwasser, M., von Blanckenburg, F., 2008. The stable Cr isotope inventory of solid Earth reservoirs determined by double spike MC-ICP-MS. Chem. Geol. 249, 294-306. https://doi.org/10.1016/j.chemgeo.2008.01.009

Shen, J., Qin, L., Fang, Z., Zhang, Y., Liu, J., Liu, W., Wang, F., Xiao, Y., Yu, H., Wei, S., 2018. Hightemperature inter-mineral $\mathrm{Cr}$ isotope fractionation: A comparison of ionic model predictions and experimental investigations of mantle xenoliths from the North China Craton. Earth Planet. Sci. Lett. 499, 278-290. https://doi.org/10.1016/j.eps1.2018.07.041

Siebert, J., Corgne, A., Ryerson, F.J., 2011. Systematics of metal-silicate partitioning for many siderophile elements applied to Earth's core formation. Geochim. Cosmochim. Acta 75, 1451-1489. https://doi.org/10.1016/j.gca.2010.12.013

Sossi, P.A., O’Neill, H.St.C., 2017. The effect of bonding environment on iron isotope fractionation between minerals at high temperature. Geochim. Cosmochim. Acta 196, 121-143.

Sossi, P.A., Moynier, F., van Zuilen, K., 2018. Volatile loss following cooling and accretion of the Moon revealed by chromium isotopes. Proc. Natl. Acad. Sci. U. S. A. 115, 10920-10925. https://doi.org/10.1073/pnas.1809060115

Teng, F., Dauphas, N., Helz, R.T., 2008. Iron Isotope Fractionation in Kilauea Iki Lava Lake. Science $320,1620-1622$. 
Trinquier, A., Birck, J.L., Allègre, C.J., 2008. High-precision analysis of chromium isotopes in terrestrial and meteorite samples by thermal ionization mass spectrometry. J. Anal. At. Spectrom. 23, 1565-1574. https://doi.org/10.1039/b809755k

Trinquier, A., Elliott, T., Ulfbeck, D., Coath, C., Krot, A.N., Bizzarro, M., 2009. Origin of Nucleosynthetic Isotope Heterogeneity in the Solar Protoplanetary Disk. Science (80-. ). 324, 374376. https://doi.org/10.1126/science.1168221

Villemant, B., Jaffrezic, H., Joron, J.-L., Treuil, M., 1981. Distribution coefficients of major and trace elements; fractional crystallization in the alkali basalt series of Chaine des Puys (Massif Central, France). Geochim. Cosmochim. Acta 45, 1997-2016.

Wang, X., Reinhard, C.T., Planavsky, N.J., Owens, J.D., Lyons, T.W., Johnson, T.M., 2016. Sedimentary chromium isotopic compositions across the Cretaceous OAE2 at Demerara Rise Site 1258. Chem. Geol. 429, 85-92. https://doi.org/10.1016/j.chemgeo.2016.03.006

Weis, D., Kieffer, B., Maerschalk, C., Barling, J., De Jong, J., Williams, G.A., Hanano, D., Pretorius, W., Mattielli, N., Scoates, J.S., Goolaerts, A., Friedman, R.M., Mahoney, J.B., 2006. Highprecision isotopic characterization of USGS reference materials by TIMS and MC-ICP-MS. Geochemistry, Geophys. Geosystems 7. https://doi.org/10.1029/2006GC001283

Wood, B.J., Wade, J., Kilburn, M.R., 2008. Core formation and the oxidation state of the Earth: Additional constraints from Nb, V and Cr partitioning. Geochim. Cosmochim. Acta 72, 1415-1426. https://doi.org/10.1016/j.gca.2007.11.036

Xia, J., Qin, L., Shen, J., Carlson, R.W., Ionov, D.A., Mock, T.D., 2017. Chromium isotope heterogeneity in the mantle. Earth Planet. Sci. Lett. 464, 103-115. https://doi.org/10.1016/j.eps1.2017.01.045

Zhu, J.M., Wu, G., Wang, X., Han, G., Zhang, L., 2018. An improved method of Cr purification for high precision measurement of $\mathrm{Cr}$ isotopes by double spike MC-ICP-MS. J. Anal. At. Spectrom. 33, 809-821. https://doi.org/10.1039/c8ja00033f

Zhu, K., Sossi, P.A., Siebert, J., Moynier, F., 2019. Tracking the volatile and magmatic history of Vesta from chromium stable isotope variations in eucrite and diogenite meteorites. Geochim. Cosmochim. Acta, accepted manuscript.

\section{Acknowledgments:}

We would like to thank Mhammed Benbakkar and Jean-Luc Piro for the ICP-AES and ICP-MS measurements, respectively. We would like to thank Paolo Sossi for his very helpful review. This project has received funding from the European Research Council (ERC) under the European Union's 
Horizon 2020 research and innovation programme (Grant Agreement No 682778 - ISOREE) and from the Clervolc Labex. This is Laboratory of Excellence ClerVolc contribution number XXX.

Conflicts of interest:

717 There are no conflicts of interest.
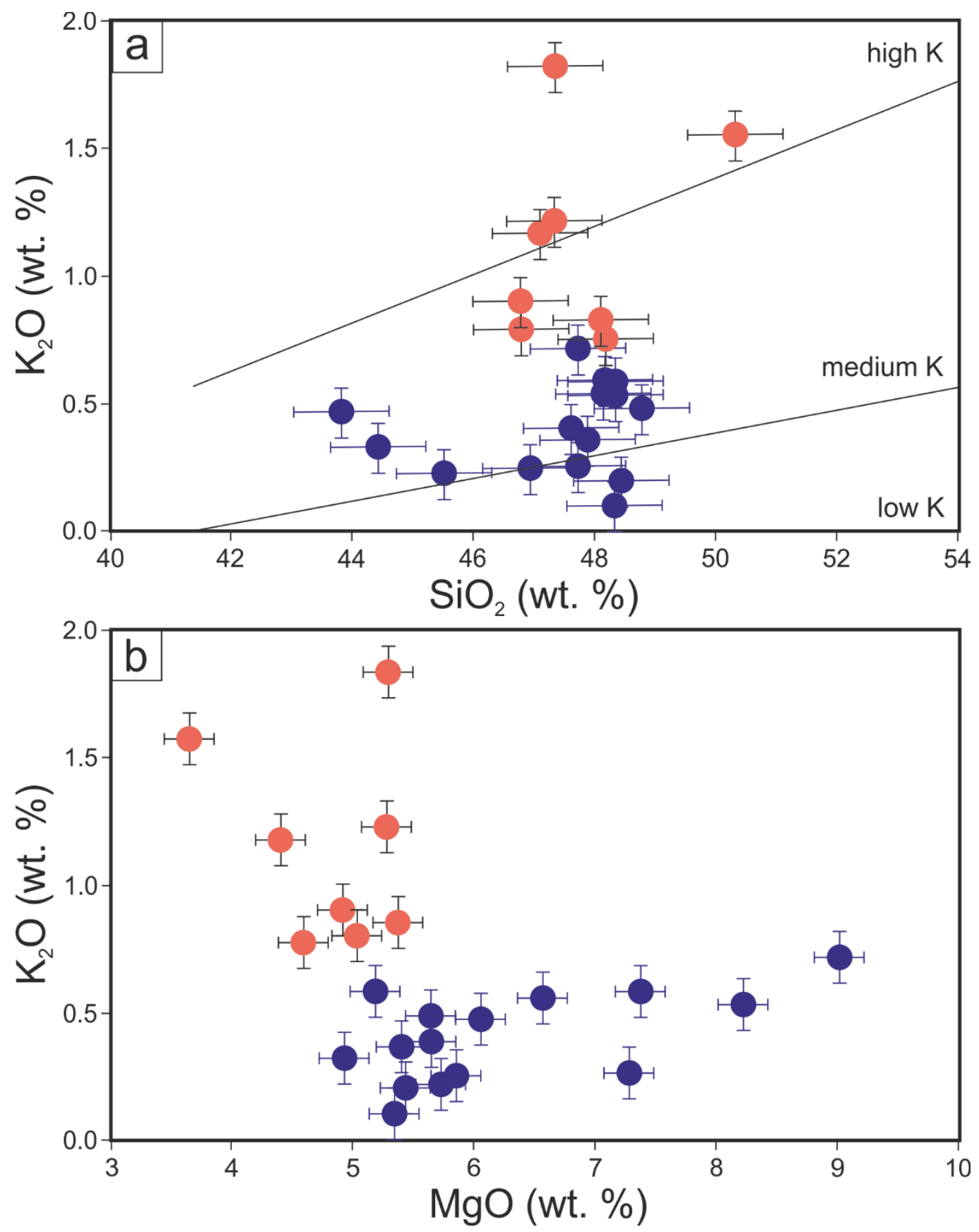

Figure 1: $\mathrm{K}_{2} \mathrm{O}$ vs (a) $\mathrm{SiO}_{2}$ and (b) $\mathrm{MgO}$ concentrations in the samples analysed in this study. The colours are for the two series (red for high-K and blue for low-K) observed in the Fangataufa samples (see text for details). 


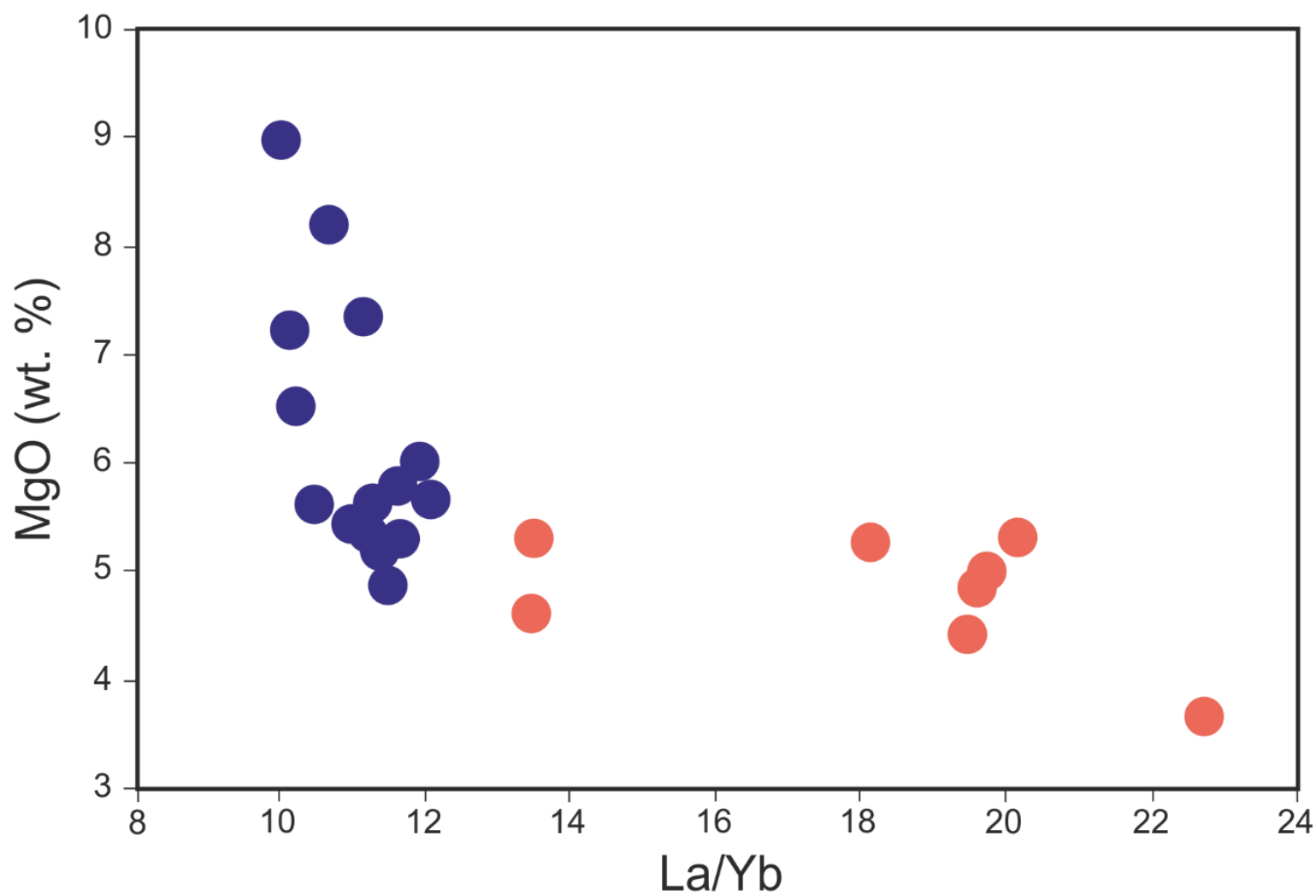

Figure 2: $\mathrm{MgO}$ vs La/Yb ratios for the samples analysed in this study. Colours defined in Fig. 1. 


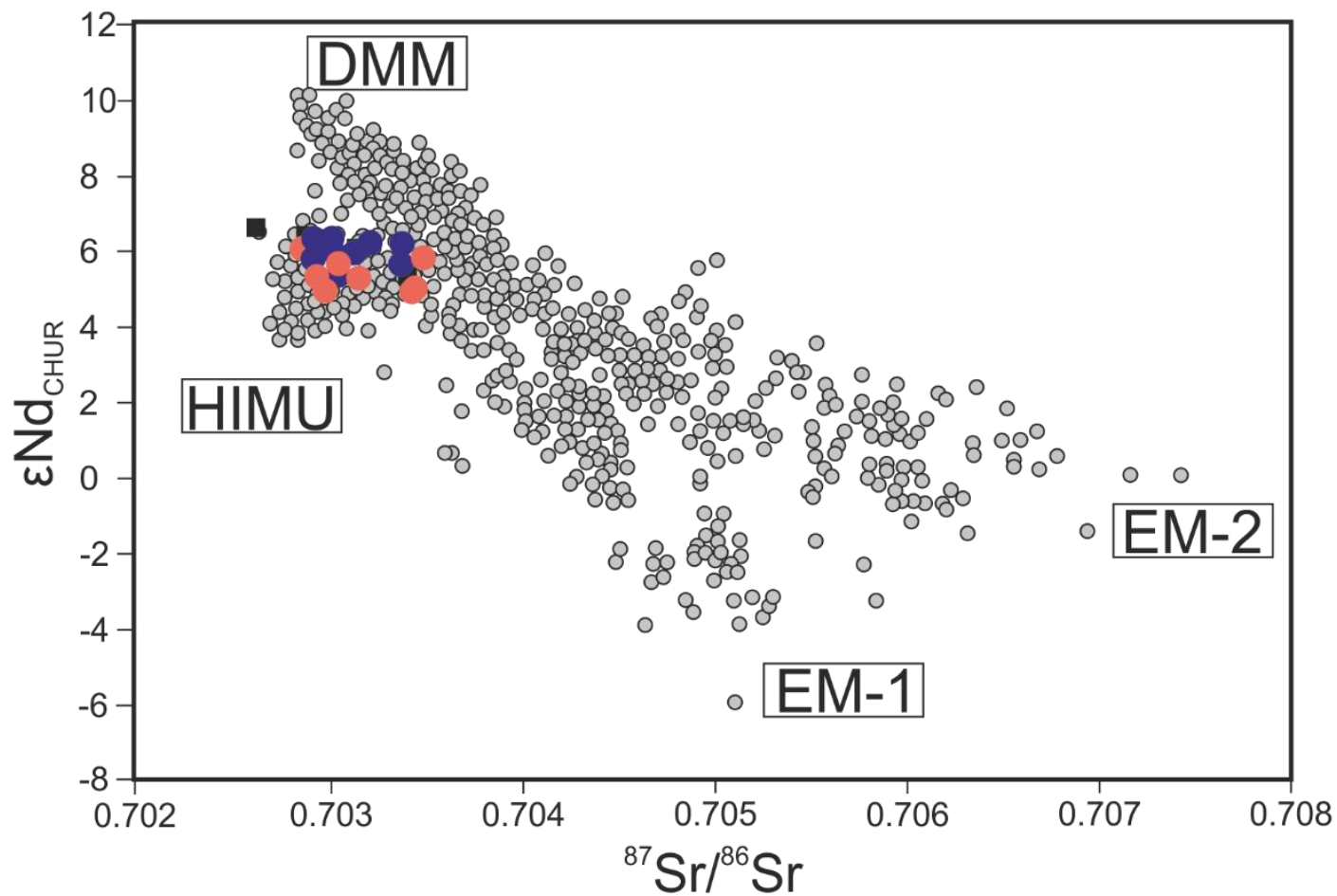

Figure 3: $\varepsilon_{\mathrm{Nd}} \mathrm{CHUR}_{\text {versus }} \mathrm{Sr}$ isotopic composition for Ocean Island basalts. The blue and red circles are the data from this study (colours defined in Figure 1). The black squares are Fangataufa samples from Bardintzeff et al. (1994). The grey circles are OIB samples from the literature. Modified after Hoffman 2007. 

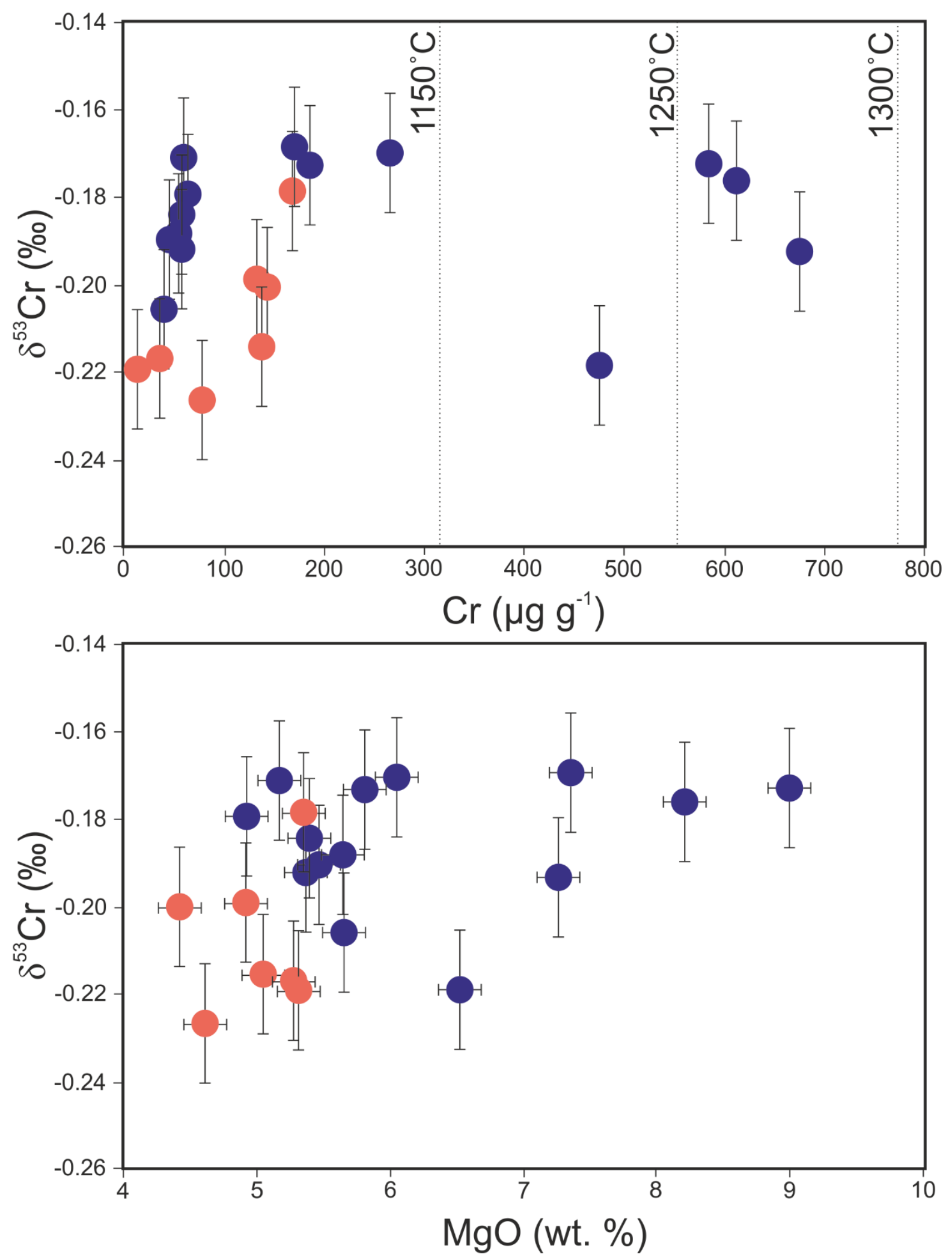

Figure 4: $\delta^{53} \mathrm{Cr}$ versus (a) $\mathrm{Cr}$ and (b) $\mathrm{MgO}$ concentrations for the samples analysed in this study. Errors bars are the external reproducibility obtained in this study (see text for details). Colours defined in Figure 1. The vertical dotted lines in (a) are the Cr saturation concentrations in silicate melts at the given temperature at QFM (Murck and Campbell 1986). 


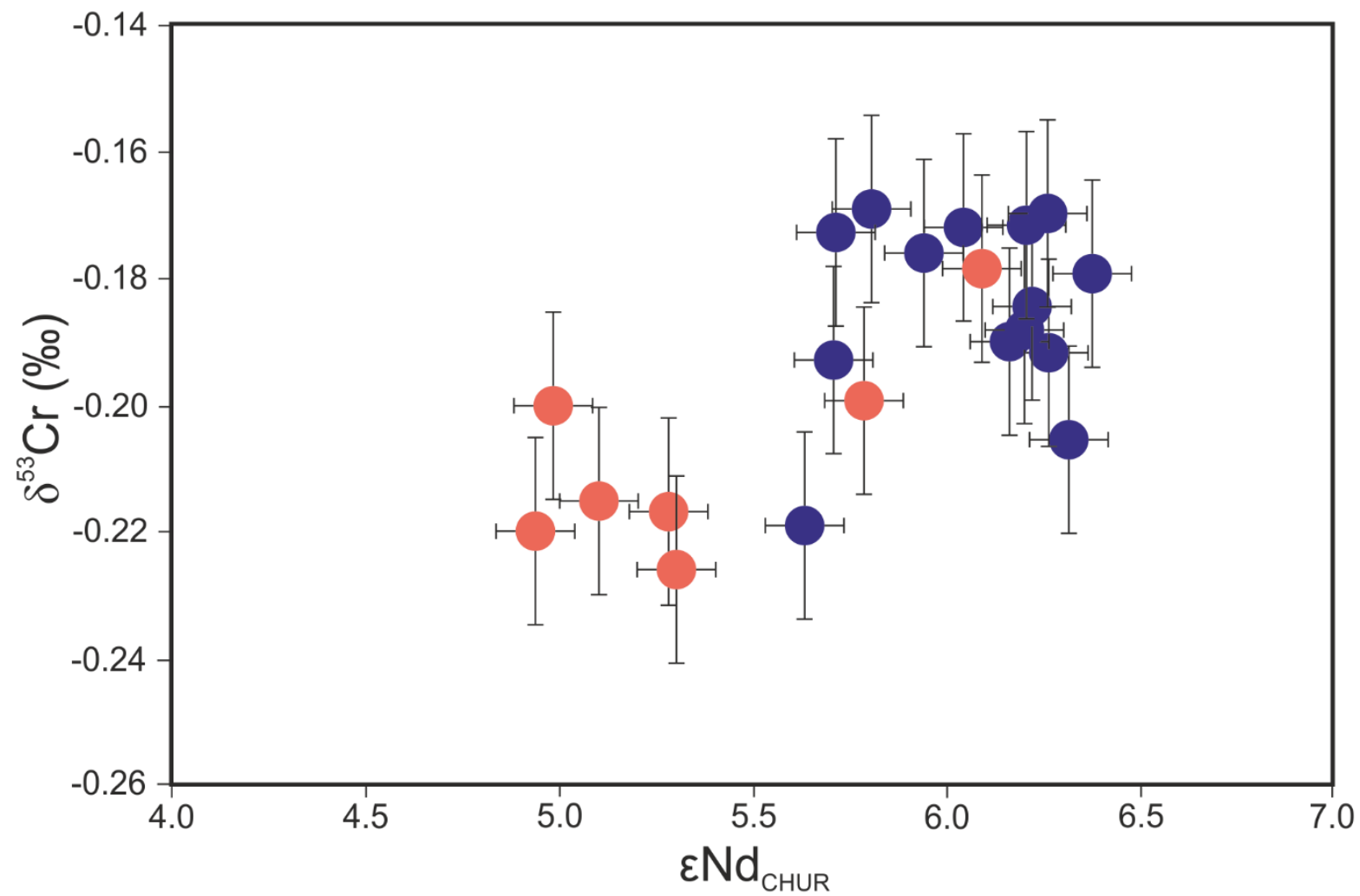

Figure 5: Cr versus Nd isotopic compositions for the Fangataufa basalts. The colour coding is defined in Figure 1. 


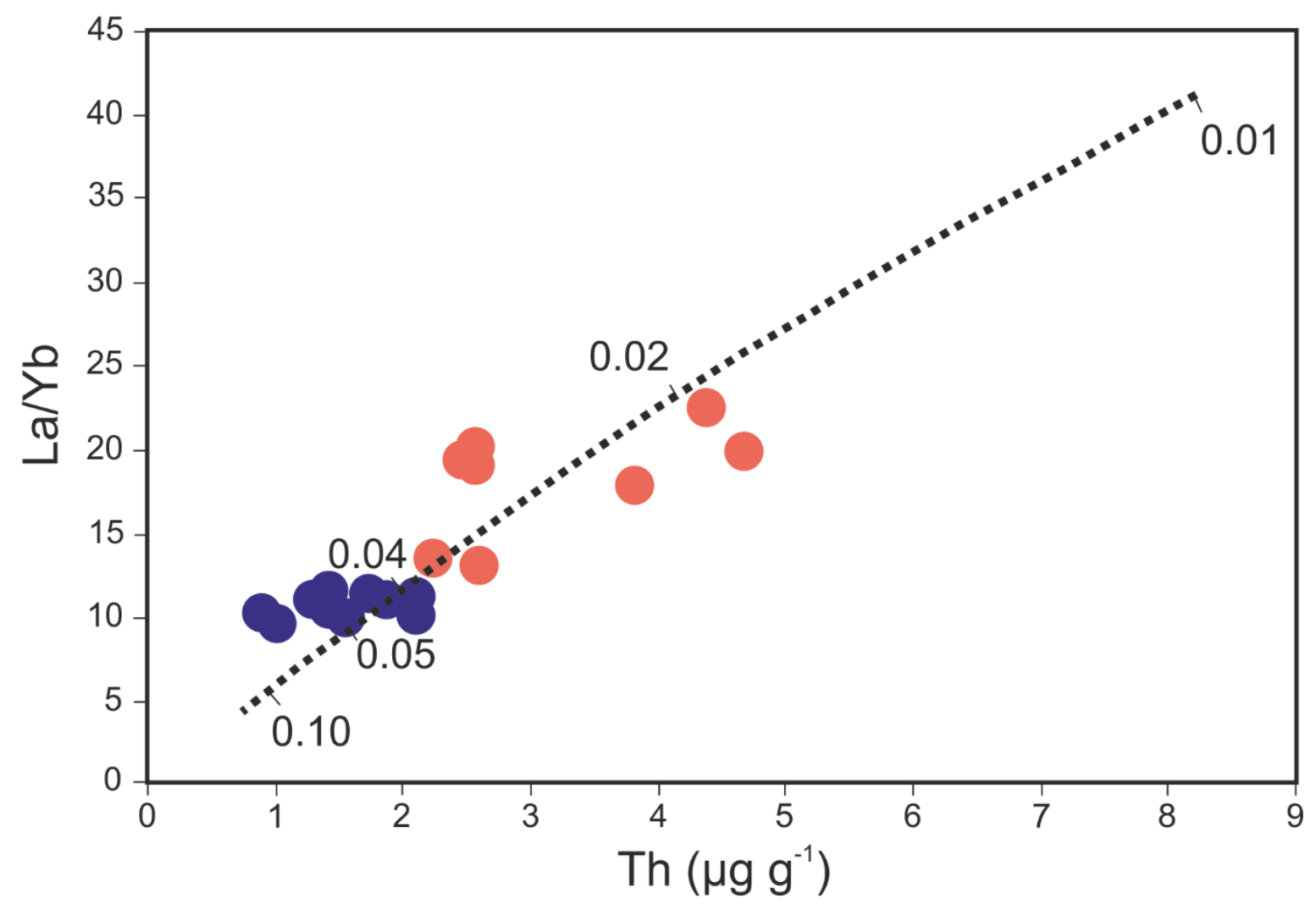

Figure 6: $\mathrm{La} / \mathrm{Yb}$ ratios versus Th concentrations in Fangataufa basalts. The colours are the same as in Figure 1. The dotted line is the partial melting model discussed in the text in the section 5.3. The numbers are the degrees of partial melting $(1=100 \%$ melt $)$. 


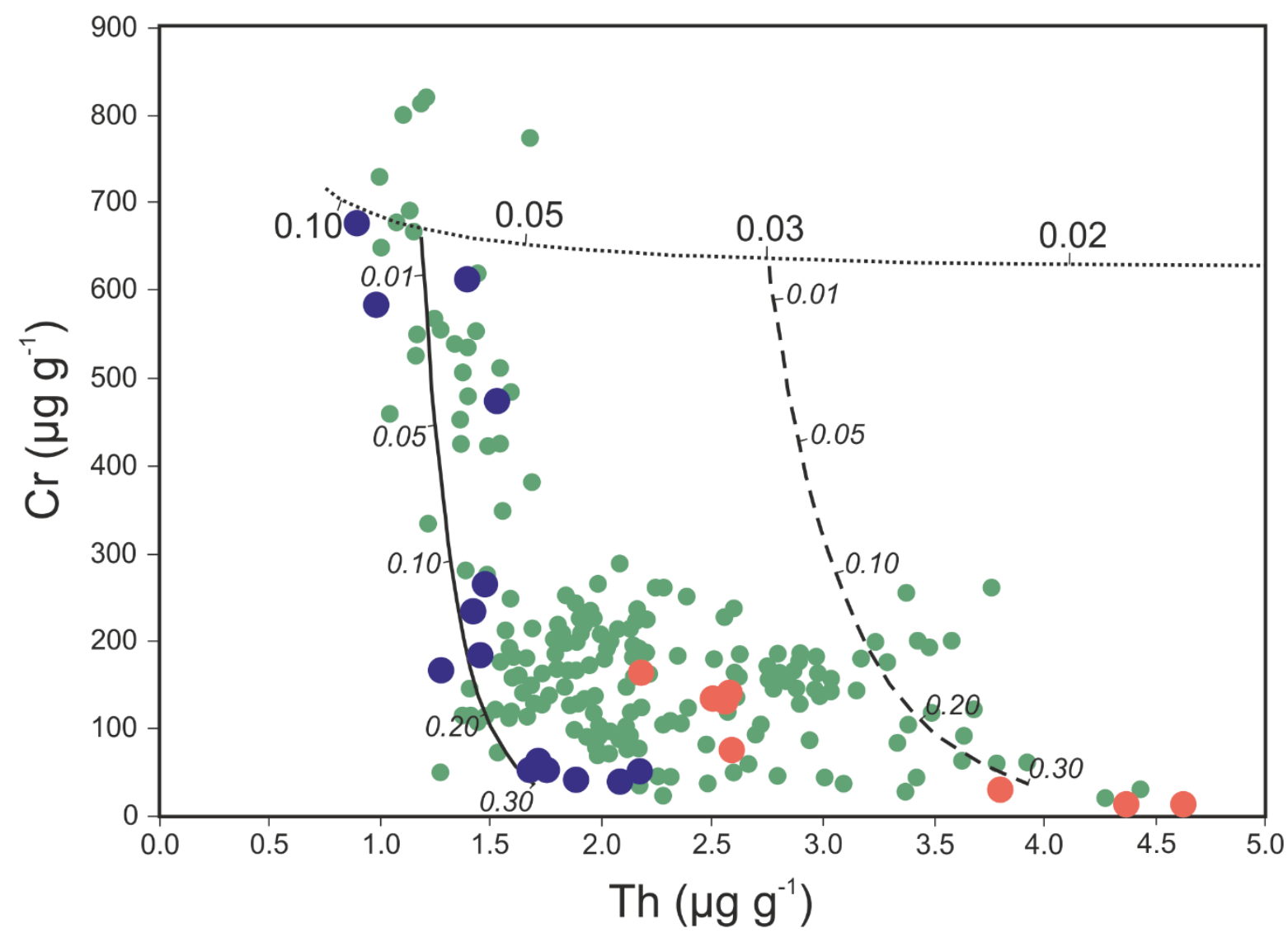

Figure 7: Chromium versus Th concentrations in Fangataufa basalts. The blue and red circles are the samples analysed in this study. The green circles are literature data together with unpublished data (Schiano et al. 1993, unpublished data, P. Schiano). The dotted line is the partial melting model discussed in the text. The solid and dashed lines are fractional crystallisation models for 7 and $3 \%$ partial melts, respectively. The numbers are the proportion of partial melting and fractional crystallisation (italic). Colours defined in Fig. 1. 


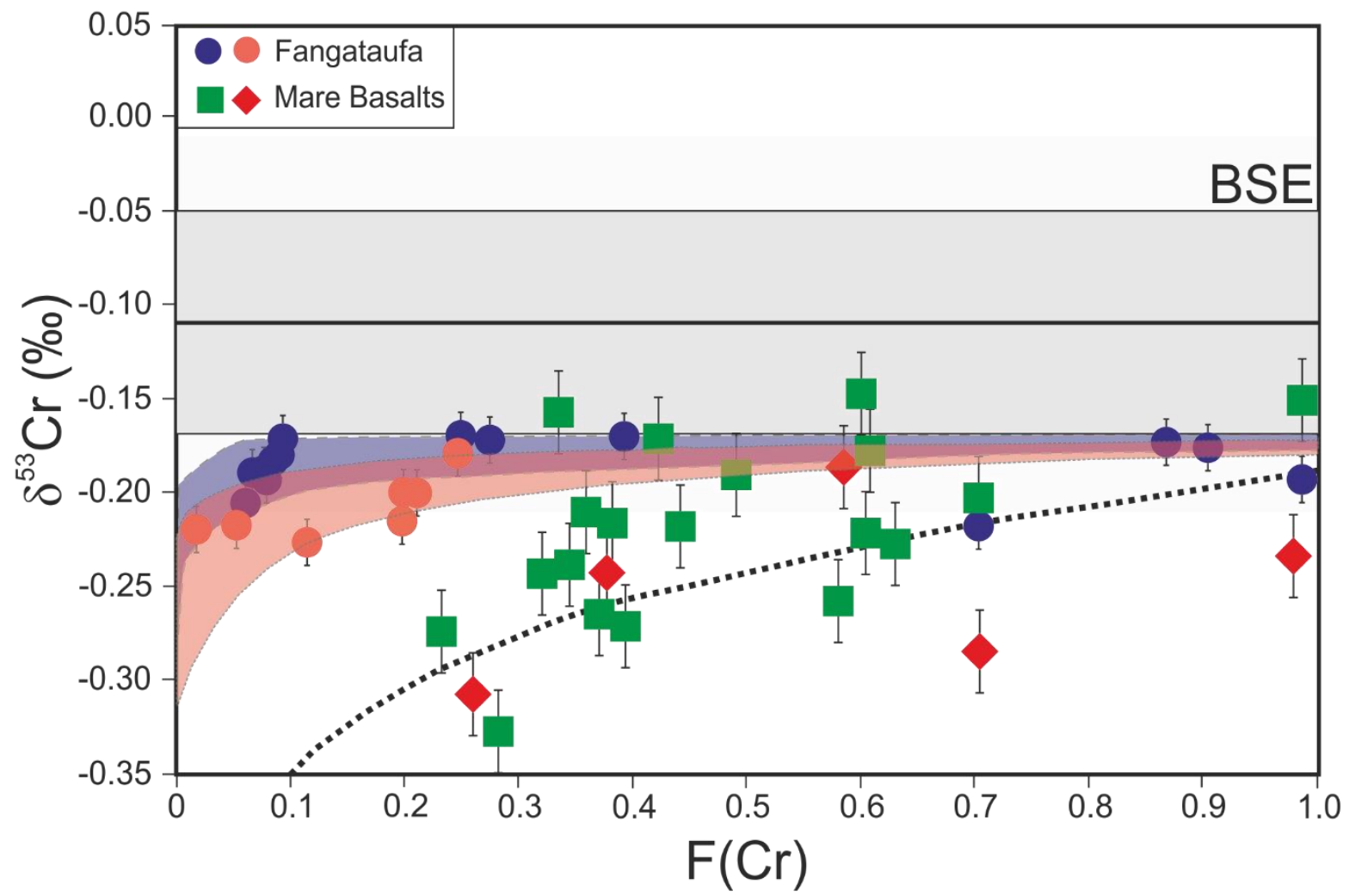

Figure 8: $\delta^{53} \mathrm{Cr}$ versus the amount of $\mathrm{Cr}$ left $(\mathrm{F})$ in the melt during fractional crystallisation for the Fangataufa basalts and the lunar basalts from Bonnand et al. (2016) and Sossi et al. (2018). F was calculated using the equation: $\mathrm{F}=\mathrm{Cr}_{\text {sample }} / \mathrm{Cr}_{\max }$, where $\mathrm{Cr}_{\max }$ is the highest concentration in both Fangataufa and lunar basalts. The grey horizontal bars are the current estimates of the BSE (dark grey: Sossi et al. 2018, light grey: Schoenberg et al. 2008). The dotted line is a Rayleigh fractionation model for lunar basalts. The blue and red shaded areas are the fractional models for the low-K and high-K suites, respectively. The isotopic fractionation $\left(\Delta^{53} \mathrm{Cr}\right)$ used for Fangataufa basalts are $-0.010 \pm 0.005$ $\%$ (low-K suite) and $-0.020 \pm 0.010 \%$ (high-K suite). For the lunar basalts, the fractionation factor is $-0.07 \%$ (see text for details). Error bars are the external reproducibility reported in each study. 
Table 1: Selected major and trace element concentrations, $\mathrm{La} / \mathrm{Yb}$ ratio and $\mathrm{Sr}, \mathrm{Nd}$ and $\mathrm{Cr}$ isotopic compositions for the samples analysed in this study.

\begin{tabular}{|c|c|c|c|c|c|c|c|c|c|c|}
\hline $\begin{array}{l}\text { Sample } \\
\text { name }\end{array}$ & $\begin{array}{l}\text { MgO* } \\
\text { wt. \% }\end{array}$ & $\begin{array}{c}\mathrm{Cr} \\
\mu \mathrm{g} \mathrm{g}^{-1} \\
\end{array}$ & $\begin{array}{c}\mathrm{Ni} \\
\mu \mathrm{g} \mathrm{g}^{-1} \\
\end{array}$ & $\begin{array}{c}\mathrm{La} \\
\mu \mathrm{g} \mathrm{g}^{-1} \\
\end{array}$ & $\begin{array}{c}\mathrm{Yb} \\
\mu \mathrm{g} \mathrm{g}^{-1} \\
\end{array}$ & $\begin{array}{c}\text { Th } \\
\mu g^{-1}\end{array}$ & ${ }^{87} \mathrm{Sr} /{ }^{86} \mathrm{Sr}$ & $\varepsilon \mathrm{Nd}_{\mathrm{CHUR}}$ & $\begin{array}{c}\delta^{53} \mathrm{Cr} \\
\% 0 \\
\end{array}$ & $\mathrm{La} / \mathrm{Yb}$ \\
\hline F107 & 7.36 & 169.1 & 144.1 & 15.2 & 1.4 & 1.3 & 0.703052 & 5.81 & -0.169 & 11.2 \\
\hline F120 & 5.82 & 186.8 & 92.7 & 17.3 & 1.5 & 1.5 & 0.702908 & 6.04 & -0.172 & 11.7 \\
\hline F122 & 7.28 & 677.7 & 292.5 & 10.1 & 1.0 & 0.9 & 0.703388 & 5.71 & -0.193 & 10.2 \\
\hline F123 & 5.72 & 236.3 & 98.2 & 17.1 & 1.4 & 1.4 & 0.702923 & 6.17 & n.d. & 12.2 \\
\hline F124 & 4.61 & 77.9 & 56.3 & 25.5 & 1.9 & 2.6 & 0.702923 & 5.30 & -0.226 & 19.4 \\
\hline F125 & 5.36 & 53.8 & 46.2 & 19.7 & 1.7 & 1.7 & 0.703218 & 6.27 & -0.192 & 11.7 \\
\hline F126 & 5.45 & 45.3 & 43.2 & 20.0 & 1.8 & 1.9 & 0.702930 & 6.15 & -0.190 & 11.0 \\
\hline F127 & 5.17 & 63.3 & 57.1 & 18.9 & 1.7 & 1.7 & 0.702902 & 6.21 & -0.171 & 11.4 \\
\hline F128 & 9.00 & 586.7 & 246.2 & 11.2 & 1.1 & 1.0 & 0.702915 & 5.71 & -0.173 & 10.0 \\
\hline F129 & 4.93 & 61.4 & 49.9 & 19.5 & 1.7 & 1.7 & 0.702927 & 6.37 & -0.179 & 11.5 \\
\hline F130 & 5.39 & 58.1 & 46.9 & 19.4 & 1.7 & 1.7 & 0.702897 & 6.22 & -0.184 & 11.3 \\
\hline F131 & 5.64 & 41.2 & 34.1 & 20.4 & 1.9 & 2.1 & 0.703018 & 6.31 & -0.205 & 12.0 \\
\hline F132 & 5.65 & 52.5 & 41.7 & 22.0 & 1.9 & 2.2 & 0.703384 & 6.20 & -0.188 & 10.2 \\
\hline F134 & 6.04 & 265.5 & 129.3 & 17.0 & 1.4 & 1.5 & 0.702998 & 6.26 & -0.170 & 10.7 \\
\hline F141 & 6.55 & 476.7 & 168.9 & 15.5 & 1.5 & 1.5 & 0.703045 & 5.63 & -0.219 & 10.2 \\
\hline F165 & 8.22 & 612.4 & 193.7 & 14.4 & 1.3 & 1.4 & 0.703129 & 5.94 & -0.176 & 10.7 \\
\hline F17 & 5.04 & 134.3 & 56.3 & 29.2 & 1.5 & 2.6 & 0.703457 & 5.10 & -0.215 & 13.5 \\
\hline F172 & 5.29 & 12.6 & 39.0 & 47.1 & 2.3 & 4.6 & 0.702989 & 4.94 & -0.219 & 19.6 \\
\hline F176 & 5.27 & 35.2 & 52.8 & 39.0 & 2.2 & 3.8 & 0.703158 & 5.28 & -0.217 & 19.7 \\
\hline F188 & 5.35 & 167.3 & 81.7 & 21.5 & 1.6 & 2.2 & 0.702865 & 6.09 & -0.179 & 20.1 \\
\hline F19 & 4.91 & 134.5 & 61.0 & 28.9 & 1.5 & 2.5 & 0.703491 & 5.79 & -0.199 & 22.8 \\
\hline F7 & 4.42 & 142.8 & 54.5 & 29.0 & 1.5 & 2.6 & 0.703429 & 4.99 & -0.200 & 10.5 \\
\hline F80 & 3.68 & 3.4 & 4.8 & 47.3 & 2.1 & 4.4 & 0.703032 & 5.87 & n.d. & 13.4 \\
\hline
\end{tabular}


Table 2: Concentrations and partition coefficients used in the partial melting and fractional crystallisation models presented in the study. See text for details. The mantle and "fertile" component concentrations are from McDonough and Sun (1995) and Gale et al. (2013), respectively. The partition coefficients are from Liu and O'Neill 2004, McKenzie and O'Nions 1995, Villemant et al. 1981 and Salters and Stracke 2004.

\begin{tabular}{lccccccc} 
& Mantle & fertile component & D $_{\text {olivine-melt }}$ & $D_{\text {opx-melt }}$ & $D_{\text {cpx-melt }}$ & $D_{\text {garnet-melt }}$ & $D_{\text {spinel-n }}$ \\
\hline $\mathrm{Cr}$ & 2625 & 250 & 0.8 & 9 & 7 & 5.5 & 170 \\
$\mathrm{Ni}$ & 1970 & 92 & 9.4 & 9.4 & 2.5 & 4.93 & 0 \\
$\mathrm{La}$ & 648 & 5210 & 0.0005 & 0.004 & 0.015 & 0.0007 & 0 \\
$\mathrm{Ce}$ & 1675 & 14860 & 0.0005 & 0.004 & 0.038 & 0.017 & 0 \\
$\mathrm{Nd}$ & 1250 & 12030 & 0.00042 & 0.012 & 0.0884 & 0.064 & 0 \\
$\mathrm{Sm}$ & 406 & 3820 & 0.0011 & 0.02 & 0.1509 & 0.23 & 0 \\
$\mathrm{Gd}$ & 544 & 4990 & 0.0011 & 0.065 & 0.16 & 1.2 & 0 \\
$\mathrm{Dy}$ & 674 & 6080 & 0.0027 & 0.065 & 0.17 & 2 & 0 \\
$\mathrm{Er}$ & 438 & 3790 & 0.013 & 0.065 & 0.18 & 3 & 0 \\
$\mathrm{Yb}$ & 441 & 3630 & 0.02 & 0.08 & 0.25 & 5.5 & 0 \\
$\mathrm{Lu}$ & 67.5 & 530 & 0.02 & 0.12 & 0.276 & 7 & 0 \\
$\mathrm{Th}$ & 79.5 & 404 & 0.00005 & 0.002 & 0.00566 & 0.009 & 0 \\
\hline $\mathrm{Cr}$
\end{tabular}

Cr and Ni concentrations are in $\left(\mu \mathrm{g} \cdot \mathrm{g}^{-1}\right)$ and REE and Th concentrations are in $\left(\mathrm{ng} \cdot \mathrm{g}^{-1}\right)$. 




Figure $\mathrm{S} 1: \mathrm{Na}_{2} \mathrm{O}+\mathrm{K}_{2} \mathrm{O}$ as a function of $\mathrm{SiO}_{2}$ concentrations for the Fangatuafa samples analysed in 945 this study. The colours are for the two series (red for high- $\mathrm{K}$ and blue for low-K) observed in the 946 Fangataufa samples (see text for details). 


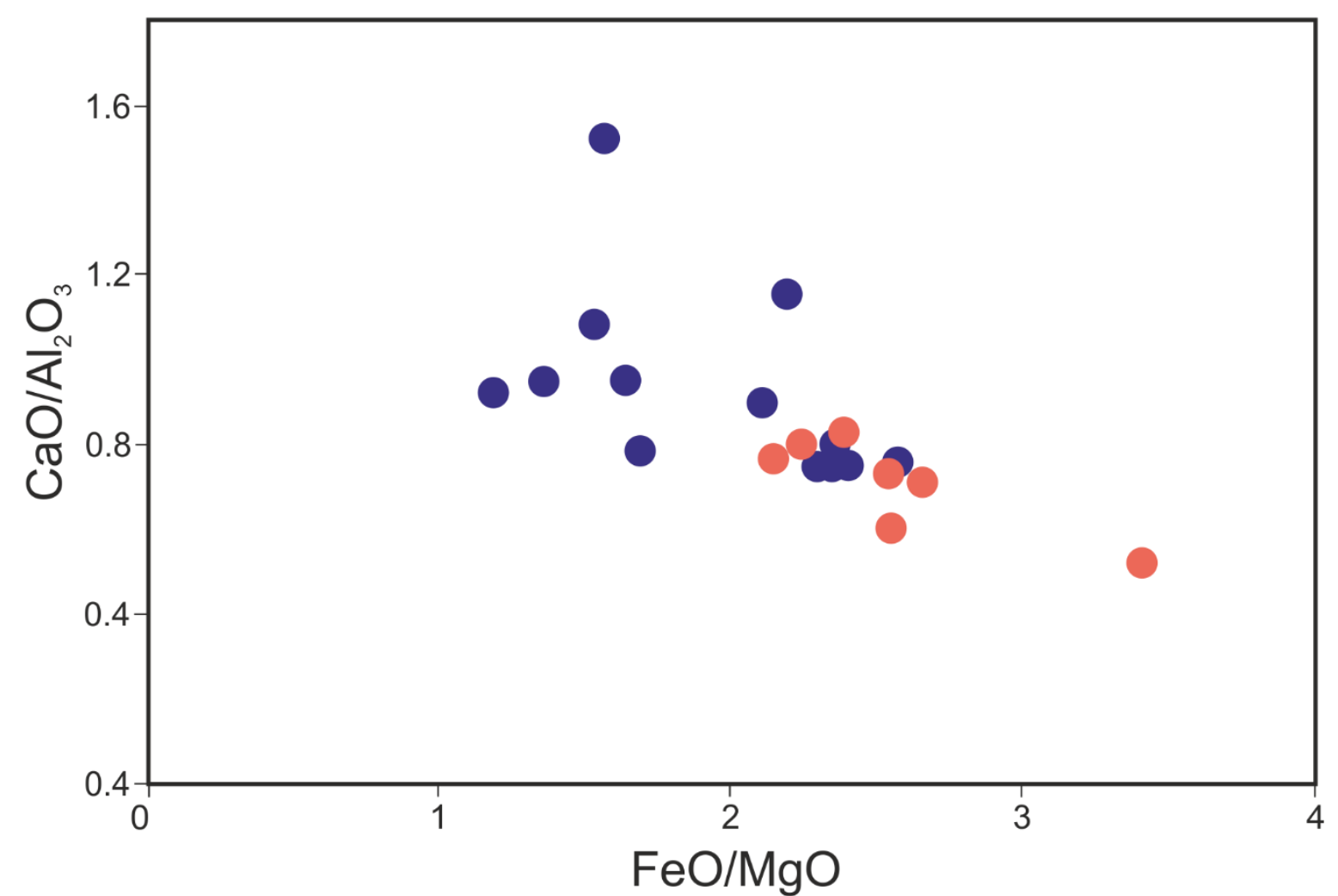

950

Figure S2: $\mathrm{CaO} / \mathrm{Al}_{2} \mathrm{O}_{3}$ versus $\mathrm{FeO} / \mathrm{MgO}$ ratios in Fangataufa basalts. The colour coding is defined in Figure S1. 


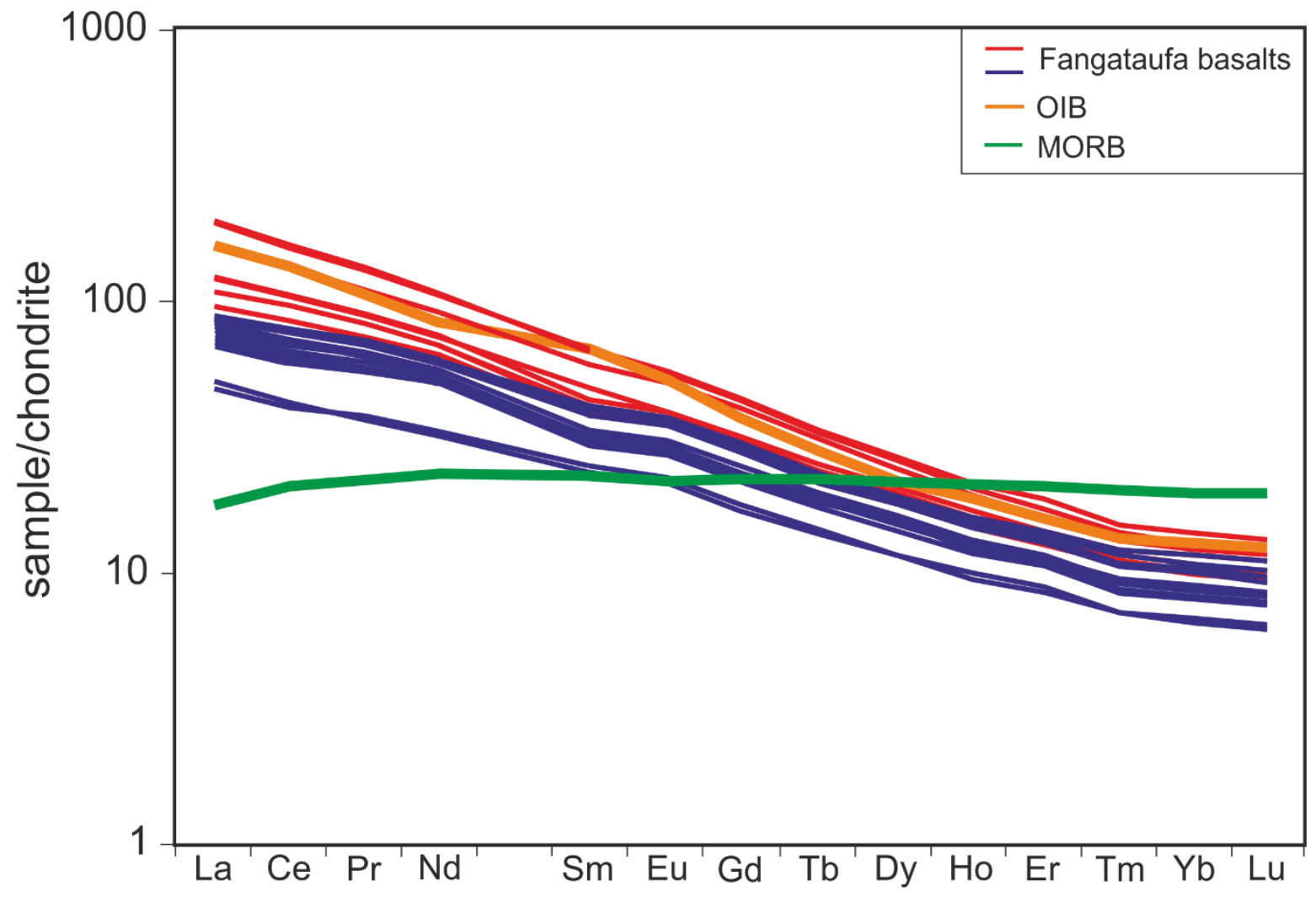

Figure S3: Chondrite normalised REE patterns for Fangataufa basalts. The OIB data is from Sun and McDonough (1989) and the MORB concentrations are rom Gale et al. (2013). The chondrite values used for normalisation is from Barrat et al. (2012). The colour coding is defined in Figure S1. 


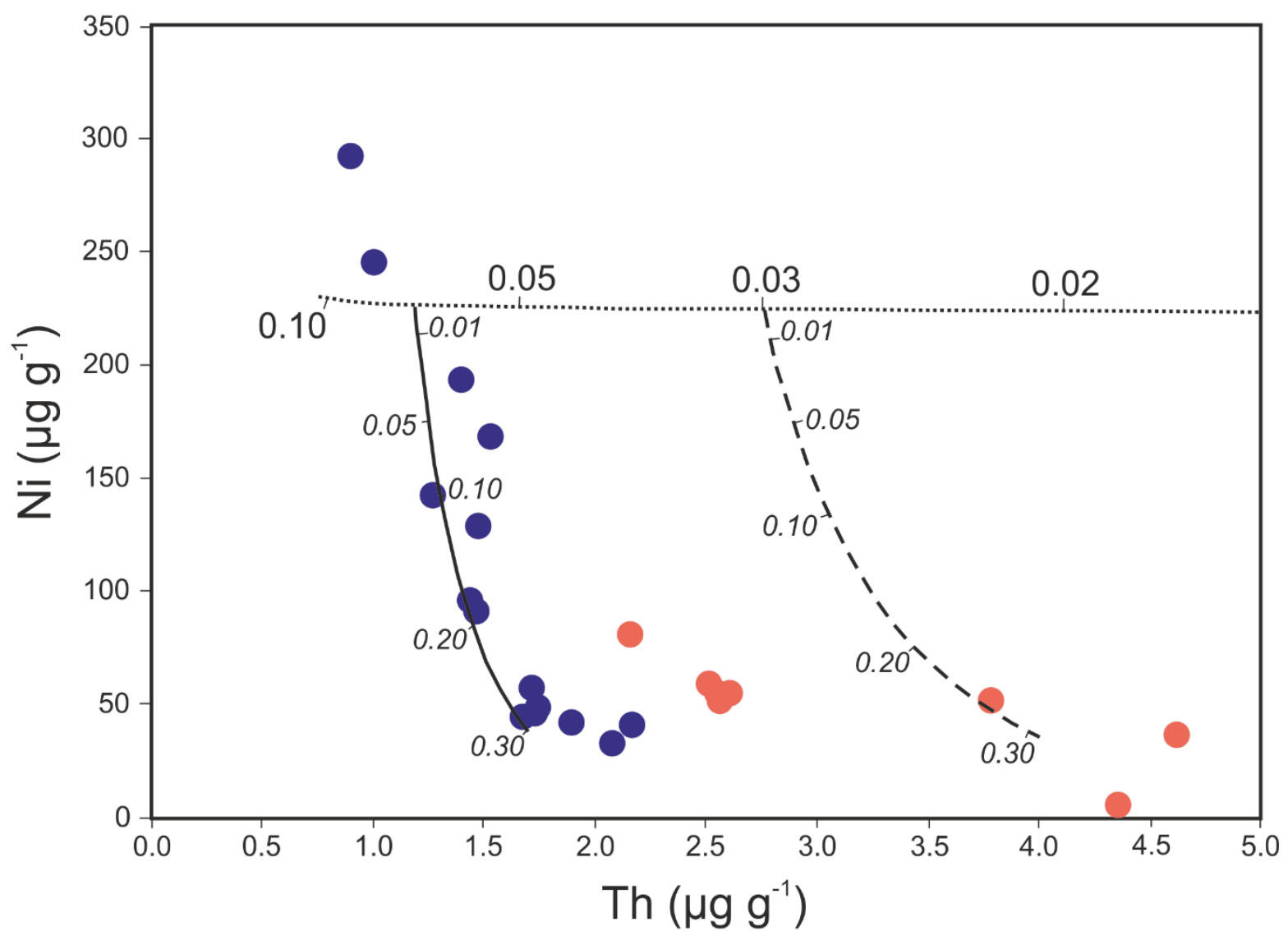

Figure S4: Nickel versus Th concentrations in Fangataufa basalts. The blue and red circles are the samples analysed in this study. The dotted line is the partial melting model discussed in the text. The solid and dashed lines are fractional crystallisation models for 7 and $3 \%$ partial melts, respectively. The numbers are the proportion of partial melting and fractional crystallisation (italic). The colour coding is defined in Figure $\mathrm{S} 1$. 


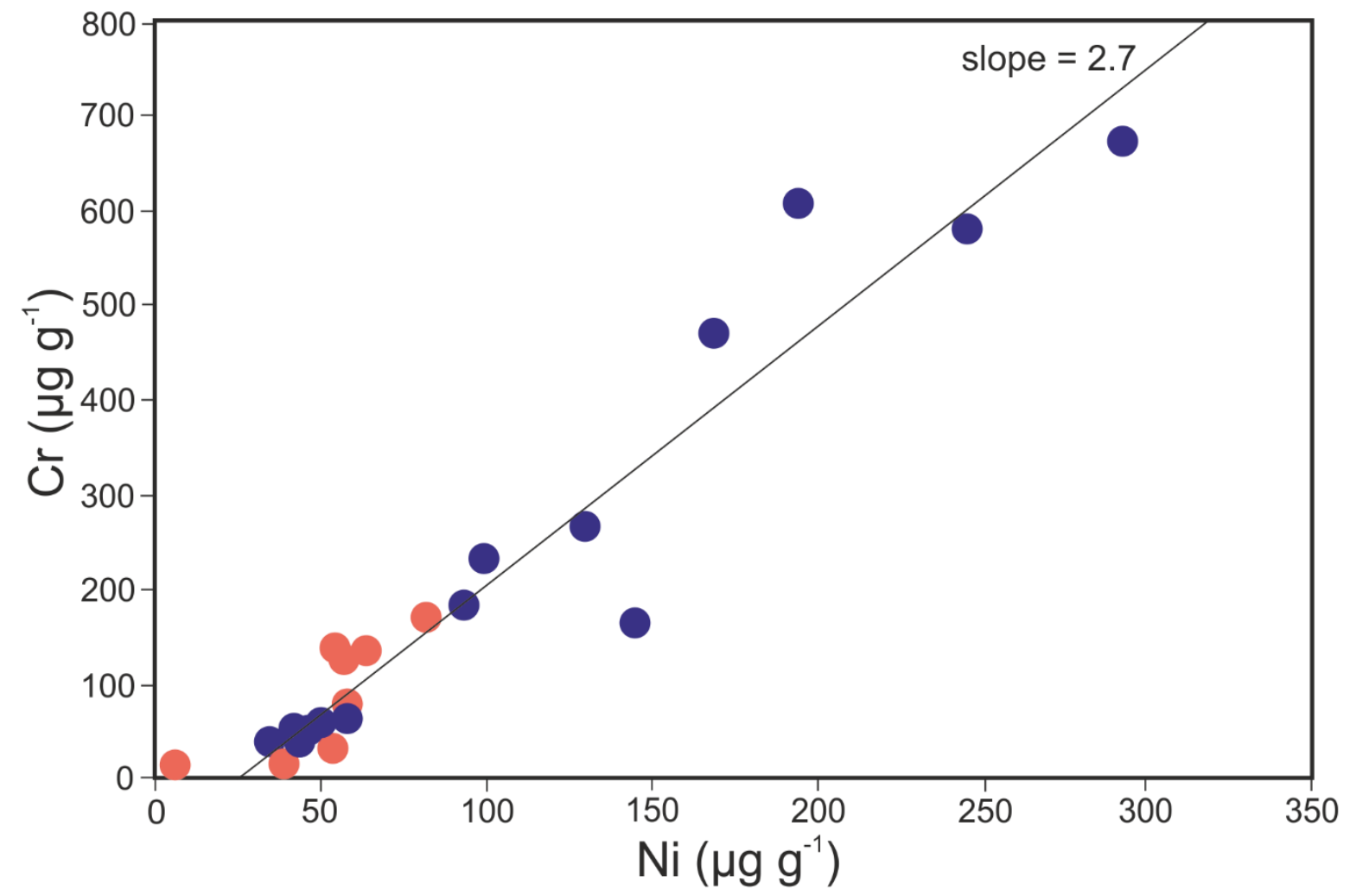

Figure S5: Cr concentrations versus Ni concentrations in the samples analysed in this study. The slope between the two concentrations is 2.7. The colour coding is defined in Figure S1. 


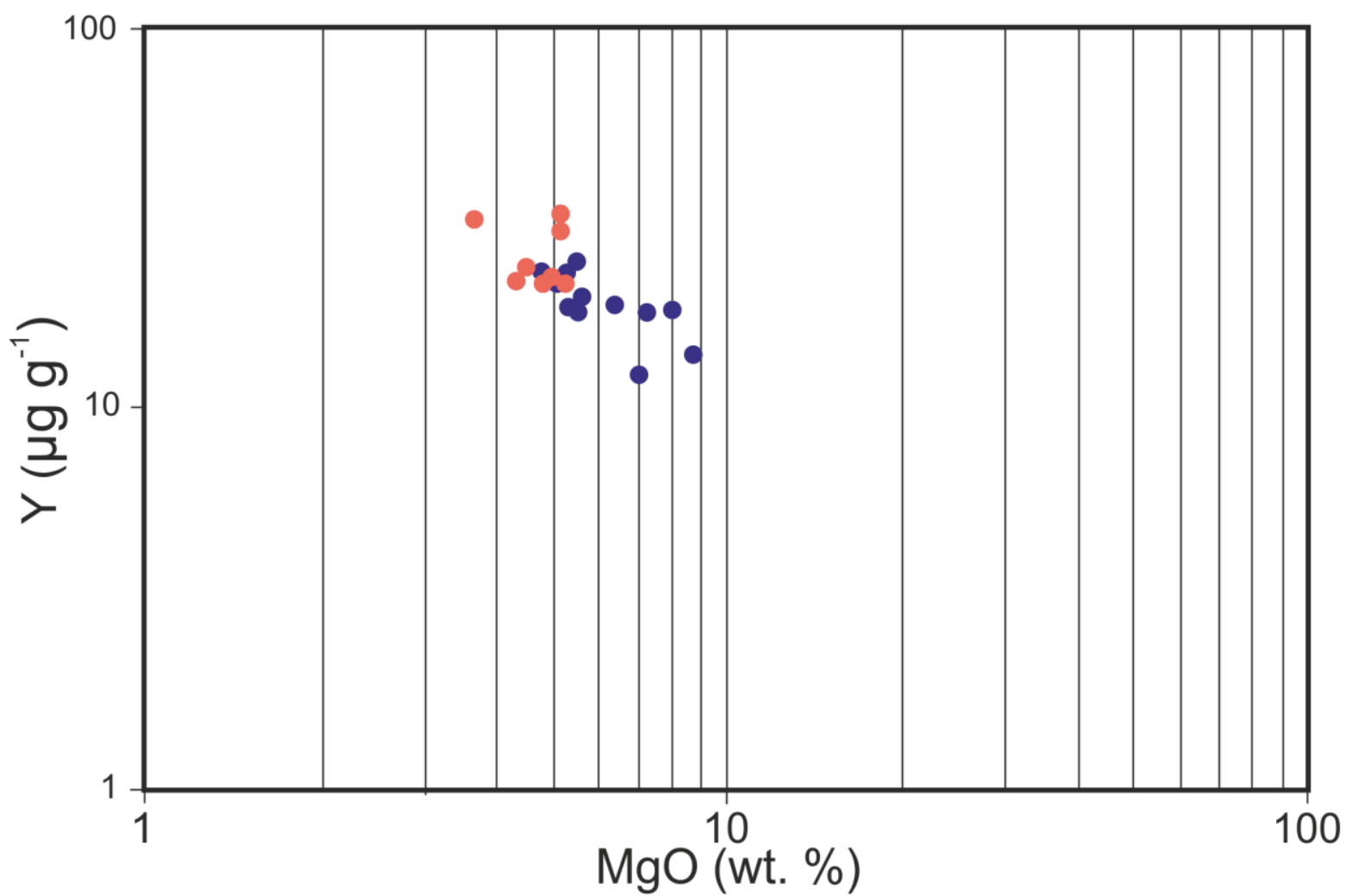

Figure S6: The variation of $\mathrm{MgO}$ and $\mathrm{Y}$ plotted on a logarithmic scale. The colour coding is defined in 997 Figure S1. 